\title{
Enhancing the Engineering Properties of Subgrade Materials Using Processed Waste: A Review
}

\author{
Samuel Y. Amakye ${ }^{1, *}$, Samuel J. Abbey ${ }^{2}$, Colin A. Booth ${ }^{2}$ (1) and Abdul-Majeed Mahamadu ${ }^{2}$ \\ 1 Department of Geography and Environmental Management, Faculty of Environment and Technology, \\ University of the West of England, Bristol BS16 1QY, UK \\ 2 Faculty of Environment and Technology, University of the West of England, Bristol BS16 1QY, UK; \\ samuel.abbey@uwe.ac.uk (S.J.A.); Colin.booth@uwe.ac.uk (C.A.B.); Abdul.Mahamadu@uwe.ac.uk (A.-M.M.) \\ * Correspondence: Samuel.amakye@uwe.ac.uk
}

Citation: Amakye, S.Y.; Abbey, S.J.; Booth, C.A.; Mahamadu, A.-M. Enhancing the Engineering Properties of Subgrade Materials Using Processed Waste: A Review. Geotechnics 2021, 1 , 307-329. https://doi.org/10.3390/ geotechnics1020015

Academic Editor: Daniel Dias

Received: 17 August 2021

Accepted: 8 October 2021

Published: 14 October 2021

Publisher's Note: MDPI stays neutral with regard to jurisdictional claims in published maps and institutional affiliations.

Copyright: () 2021 by the authors. Licensee MDPI, Basel, Switzerland. This article is an open access article distributed under the terms and conditions of the Creative Commons Attribution (CC BY) license (https:// creativecommons.org/licenses/by/ $4.0 /)$.

\begin{abstract}
Subgrade materials refer to the original ground underneath a road pavement, when these materials are made up of expansive soil it is referred to as expansive subgrade. Sometimes, these materials do not have sufficient capacity to support the weight of the road pavement and traffic load, which means they require some form of modification and re-engineering to enhance their load capacity. Chemical modification techniques using traditional stabilisers (such as cement and lime) have proved to be an effective means of subgrade stabilisation. However, high costs and environmental concerns associated with the use and production of these additives have highlighted the need for more sustainable and environmentally friendly substitutes. This study reviews the use of industrial by-products and other waste materials used for subgrade stabilisation, focusing on the sustainability of using processed wastes and how they alter the engineering properties of weak subgrade, compared to the use of cement and also reviews the availability of processed waste materials in quantities sufficient to meet the current demand for subgrade stabilisation. The findings illustrate that, processed waste is less expensive and has better sustainability credentials compared to cement. Moreover, processed wastes are available in sufficient quantities to meet existing demands for subgrade stabilisation. Therefore, it is recommended that the use of processed wastes should be promoted and utilised to improve and enhance the geotechnical properties of weak subgrade materials where possible.
\end{abstract}

Keywords: expansive soil; subgrade stabilisation; engineering properties; California bearing ratio; unconfined compressive strength

\section{Introduction}

Expansive subgrade materials in road pavement structures can cause defects and failure in road pavement structure leading to high cost of maintenance and sometimes total redesign and reconstruction of the road infrastructure. The damage caused by expansive subgrade in road structure runs into many billions of dollars, which is notably more than damages caused by flooding [1]. For instance, the UK economy alone over the past ten years has suffered costs in excess of GBP 3 billion, making it the most damaging geohazard [2,3]. Oftentimes, subgrade materials do not have sufficient capacity to support the weight of the road pavement and traffic load and will require some sort of modification and reengineering to enhance their load capacity. Chemical subgrade stabilisation techniques, using traditional binders (such as cement and lime) are regularly used to stabilise expansive subgrade materials and have proven to be an effective approach. However, using cement and lime in road subgrade stabilisation has proved very costly and also unsustainable due to environmental effects associated with the use of cement and its production [4,5]. Cement is the most widely used material on earth after water however, cement is considered the most destructive material on earth [2]. Cement production produces a large amount of (4-8\%) the world's $\mathrm{CO}_{2}$, destroying natural resources such as vegetation, with limestone 
discharging wastewater and sludge from concrete batch plants having a harmful effect on the water ecosystem [6]. Processed wastes derived from industrial by-products that are often dumped in landfills can be used as additives in road subgrade stabilisation. The use of processed wastes to improve the engineering and geotechnical properties of expansive road subgrade is less costly than cement and lime and can reduce the amount of greenhouse gas emitted into the atmosphere. Processed waste (such as ground granulated blast furnace slag (GGBS), brick dust waste synthetic fibres, plastic waste and fly ash amongst other construction and demolition wastes) have been used in subgrade stabilisation to improve their engineering properties of road pavement and concomitantly reduce overall construction costs. Figure $1 \mathrm{a}, \mathrm{b}$ shows areas in the UK and the US that are susceptible to swell-shrink effects, and Figure 1c,d shows a contours plot of swelling potential in Louisiana, while Figure 2a,b shows a typical wet and dry expansive soil with high potential to swelling and shrinkage. Figure $2 c, d$ shows a road pavement defect caused by expansive subgrade. Tables 1 and 2 show the estimated cost of damage due to expansive soils in some countries and annual damage in the US from expansive soils.

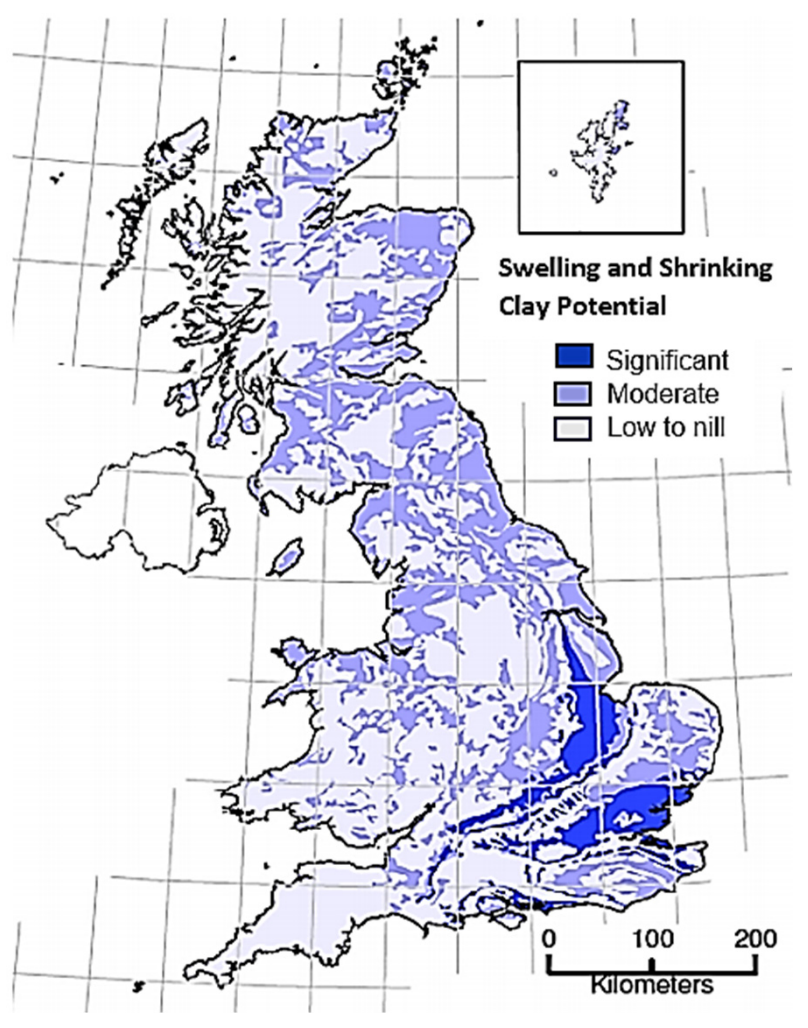

(a)
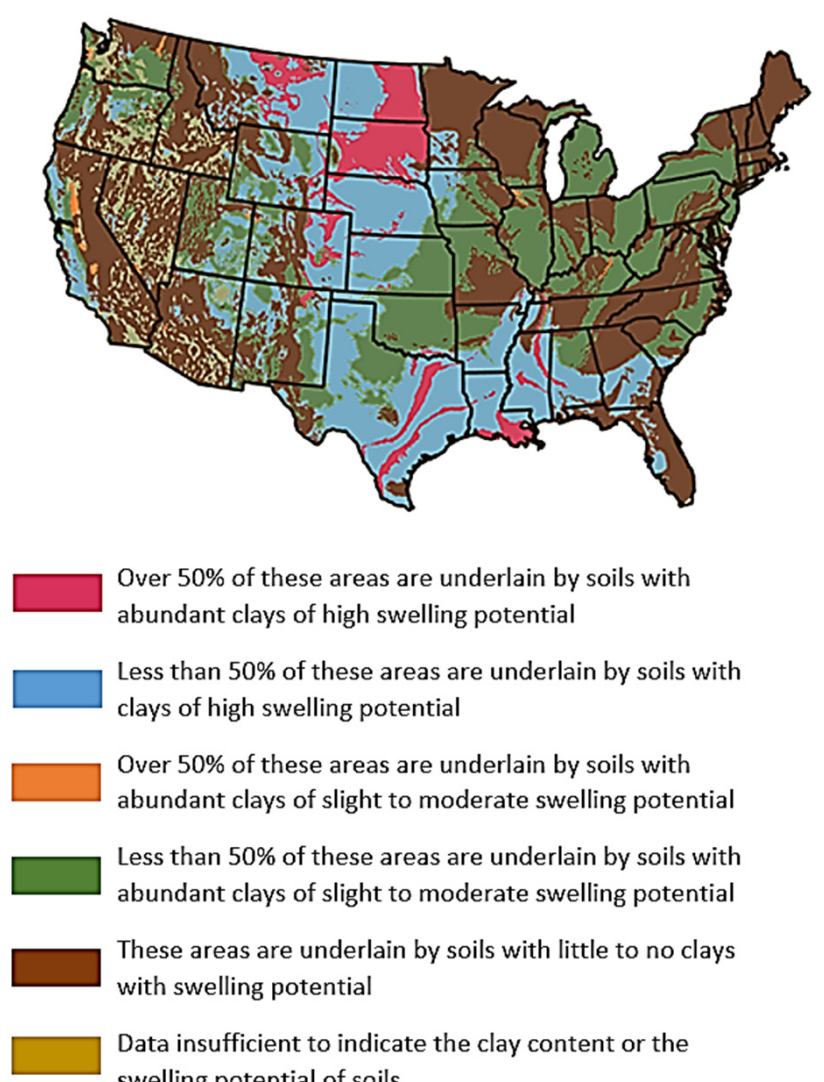

Over $50 \%$ of these areas are underlain by soils with abundant clays of high swelling potential

Less than $50 \%$ of these areas are underlain by soils with clays of high swelling potential

Over $50 \%$ of these areas are underlain by soils with abundant clays of slight to moderate swelling potential

Less than $50 \%$ of these areas are underlain by soils with abundant clays of slight to moderate swelling potential

These areas are underlain by soils with little to no clays with swelling potential

Data insufficient to indicate the clay content or the swelling potential of soils

(b)

Figure 1. Cont. 


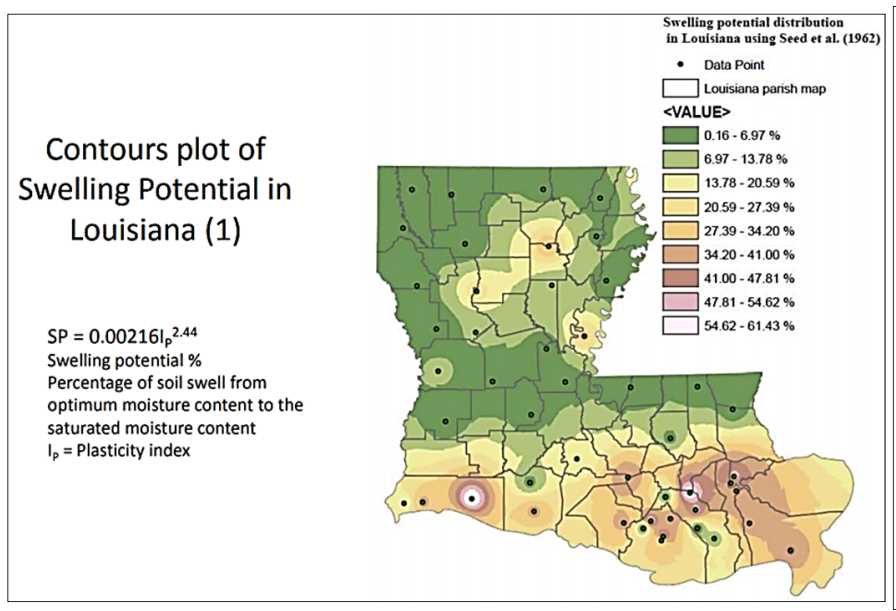

(c)

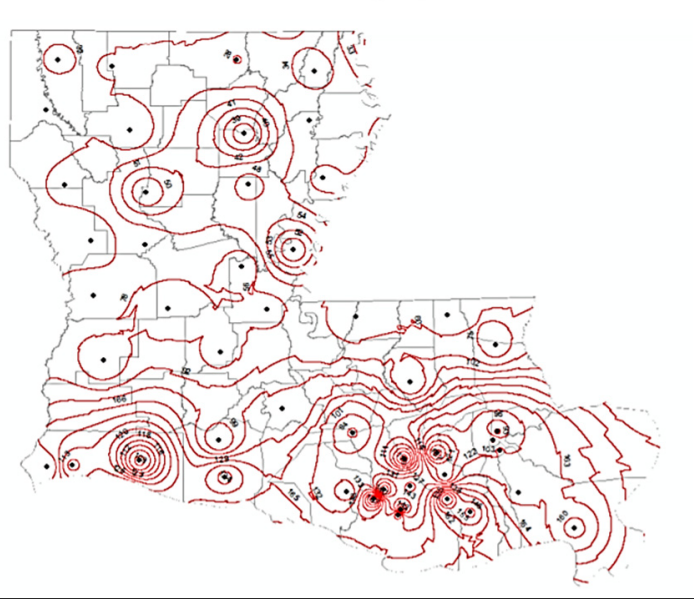

(d)

Figure 1. (a) Shrink-swell potential areas in the UK [3]; (b) Areas in the US where soils are susceptibileto swelling [7]; (c) contours plot of swelling potential in Louisiana [7]; (d) contours plot of swelling potential in Louisiana [7].

Table 1. Estimated cost of damage due to expansive soils in some countries.

\begin{tabular}{ccc}
\hline Country & Amount (USD) & Reference \\
\hline UK & $>3.7$ billion & {$[8]$} \\
China & $>1$ billion & {$[9]$} \\
France & $>2.71$ billion & {$[10]$} \\
India & $>73$ million & {$[11]$} \\
Saudi Arabia & $>300$ million & {$[12]$} \\
Sudan & $>6$ million & {$[13]$} \\
USA & $>9$ billion annually & {$[9]$} \\
\hline
\end{tabular}

Table 2. Annual damage in the US from expansive soils [7].

\begin{tabular}{cc}
\hline Category & Annual Damage (US\$) \\
\hline Highways and streets & $4,550,000,000$ \\
Commercial buildings & $1,440,000,000$ \\
Single family homes & $1,200,000,000$ \\
Walks, drives and parking areas & $440,000,000$ \\
Buried utilities and services & $400,000,000$ \\
Multi-story buildings & $320,000,000$ \\
Airport installations & $160,000,000$ \\
Involved in urban landslides & $100,000,000$ \\
Other & $390,000,000$ \\
Total annual damage (1987) & $9,000,000,000$ \\
\hline
\end{tabular}

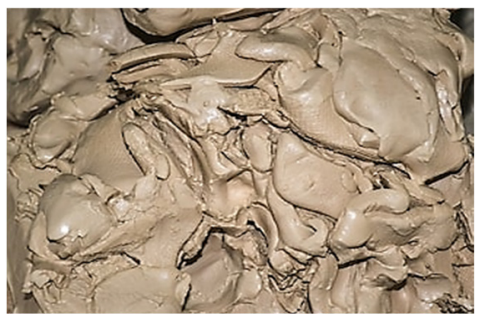

(a)

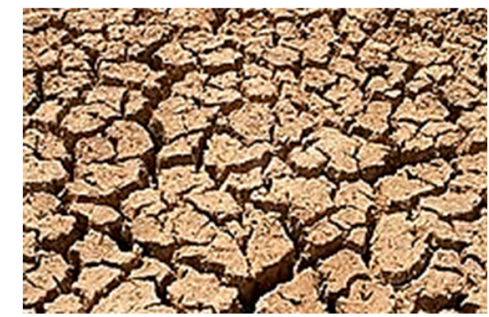

(b)

Figure 2. Cont. 


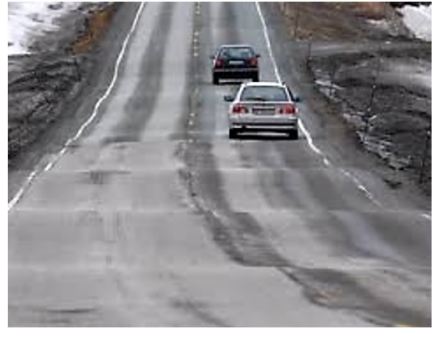

(c)

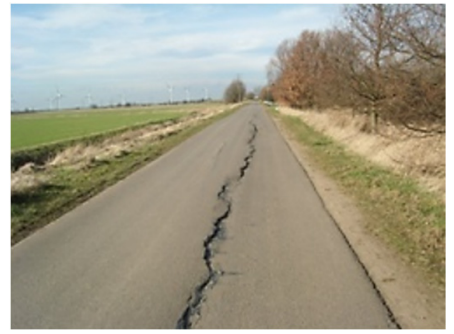

(d)

Figure 2. (a) Typical wet expansive soil [14]; (b) typical dry expansive soil [15]; (c) uplifting of flexible pavement due to expansive soil [16]; (d) typical longitudinal crack developed on pavements over expansive clays [17].

\section{Scope of the Study}

This study reviews the use of processed waste materials for road subgrade stabilisation, with a focus on their availability, the costs of processing the waste and revealing associated environmental effects compared to those of cement production. The study also reviews the effects of using processed waste materials on the engineering properties of road subgrade (such as unconfined compressive strength (USC), California bearing ration (CBR), tensile strength and shrink-swell of expansive subgrade materials stabilised using processed waste).

\section{Characteristics and Minerals Structure of Clay Soil}

The swelling ability of expansive subgrade materials depends on the total internal and external areas of its mineral particles, such as montmorillonite expandable illite and vermiculite or if the liquid limit of the soil exceeds $50 \%$ and the plasticity index exceeds $30 \%[2,11]$. The types of expansive clay soils include smectite, bentonite, montmorillonite, beidellite, vermiculite, attapugite, nontronite and chlorite. The enlargement of the capillary films in clay minerals can cause swelling to occur when water is absorbed through their outer surface [18,19]. According to [20], expansive soils contain smectite clay materials which when view under a microscope looks like layered sheets due to their moistureretaining abilities. When water is introduced to expansive soil, the water molecules are pulled into the gaps between the clay plates, which force the plates [21,22]. The hydraulic conductivity and other engineering properties of clayey soil are influenced by the diffused double layer. Clay minerals are major constituents of fine-grained sediments and rocks including mudrocks, shales, claystones, clayey siltstones, clayey oozes and argillites [2,23]. Clay minerals are defined by geologist as hydrous layer aluminosilicates with particle sizes $<2 \mu \mathrm{m}$, whilst engineers defined clay as any mineral particle $<4 \mu \mathrm{m}$ which are a diverse group of hydrous layer aluminosilicate that constitutes the greater part of the phyllosilicate family of minerals.

The physical structure of montmorillonite particles in clay is generally perceived in sheets and layers. Each layer is composed of two types of structural sheets namely octahedral and tetrahedral. The tetrahedral sheet is composed of silicon-oxygen tetrahedral linked to neighbouring tetrahedra by sharing three corners resulting in a hexagonal network. The remaining four corners of each tetrahedron form a part of the adjacent octahedral sheet which are normally composed of aluminium or magnesium in six-fold coordination with oxygen from the tetrahedral sheet and with hydroxyl [24,25]. Figure 3 shows the expansion of a single smectite grain after introducing water between clay layers, Table 3 shows swell potential of soil based on their liquid limit, Table 4 shows the classification of shrink potentials of expansive soil based on their plasticity index and Table 5 shows the relation of soil index properties and probable volume change for highly plastic soils, Table 6 shows typical values for cation exchange capacities. Figure 4a shows clay mineral structure, Figure $4 \mathrm{~b}$ shows bentonite clay structure, Figure $4 \mathrm{c}$ shows kaolinite clay structure. 


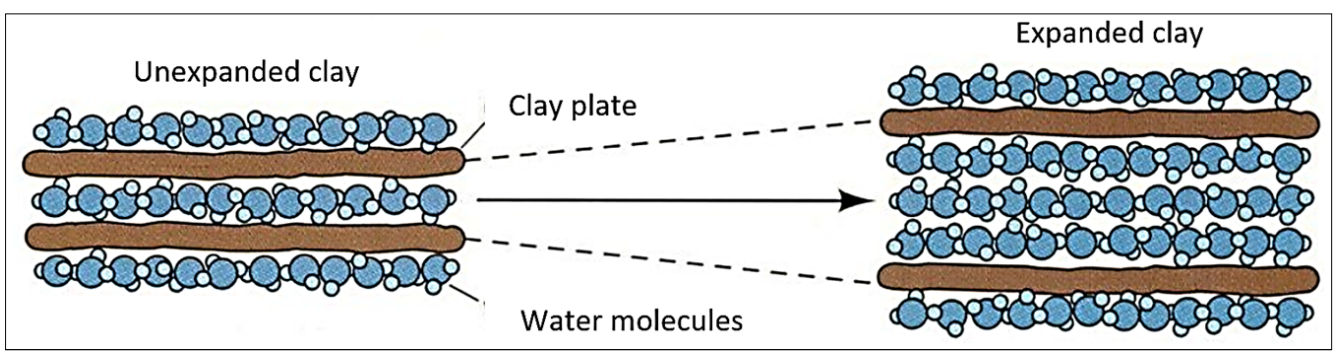

Figure 3. Expansion of a single smectite grain [20].

Table 3. Swelling potential of soils based on liquid limit [26].

\begin{tabular}{cc}
\hline Liquid Limit & Classification \\
\hline $0-20$ & Non-Swelling \\
$20-35$ & Low-Swelling \\
$35-50$ & Medium-Swelling \\
$50-70$ & High-Swelling \\
$70-90$ & Very High-Swelling \\
$>90$ & Extra High-Swelling \\
\hline
\end{tabular}

Table 4. Classification of shrink potentials based on plasticity index [3].

\begin{tabular}{ccc}
\hline PI (\%) & Clay Fraction & Shrinkage Potential \\
\hline & & $\mathbf{( < 0 . 0 0 2} \mathbf{~ m m})$ \\
\hline 35 & $>95$ & Very High \\
$22-48$ & $60-95$ & High \\
$12-32$ & $30-60$ & Medium \\
$<18$ & $<30$ & Low \\
\hline
\end{tabular}

PI = plasticity index.

Table 5. Relation of soil Index properties and probably volume change for highly plastic soils [27].

\begin{tabular}{|c|c|c|c|c|}
\hline \multicolumn{3}{|c|}{ Data from Index Tests ${ }^{1}$} & \multirow{2}{*}{$\begin{array}{l}\text { Estimation of Probable } \\
\text { Expansion }{ }^{2} \text {, Percent Total } \\
\text { Volume Change (Dry to } \\
\text { Saturated Condition) }\end{array}$} & \multirow[b]{2}{*}{$\begin{array}{l}\text { Degree of } \\
\text { Expansion }\end{array}$} \\
\hline $\begin{array}{l}\text { Colloid Content Percent } \\
\text { Minus } 0.00004 \text { in. } \\
(0.001 \mathrm{~mm})(\text { ASTM D422) }\end{array}$ & $\begin{array}{l}\text { Plasticity Index } \\
\text { (ASTMD4318) }\end{array}$ & $\begin{array}{c}\text { Shrinkage Limit } \\
\text { Percent (ASTM D427) }\end{array}$ & & \\
\hline$>28$ & $>35$ & $>11$ & $>30$ & Very High \\
\hline $20-31$ & $24-41$ & $7-12$ & $20-30$ & High \\
\hline $13-23$ & $15-28$ & $10-16$ & $10-20$ & Medium \\
\hline$<15$ & $<8$ & $<15$ & $<10$ & Low \\
\hline
\end{tabular}

${ }^{1}$ All three index tests should be considered in estimating expansive properties. ${ }^{2}$ Based on a vertical loading of $1.0 \mathrm{psi}(0.007 \mathrm{MPa})$. For higher loadings the amount of expansion is reduced, depending on the load and on the clay characteristics.

Table 6. Typical values for cation exchange capacities [25].

\begin{tabular}{cc}
\hline Liquid Limit & $\mathbf{m e q} / \mathbf{1 0 0} \mathbf{g}$ \\
\hline Kaolinite & $3-18$ \\
\hline Halloysite & $5-40$ \\
\hline Chlorite & $10-40$ \\
\hline Illite & $10-40$ \\
\hline Montmorillonite & $60-150$ \\
\hline Vermiculite & $100-215$ \\
\hline
\end{tabular}




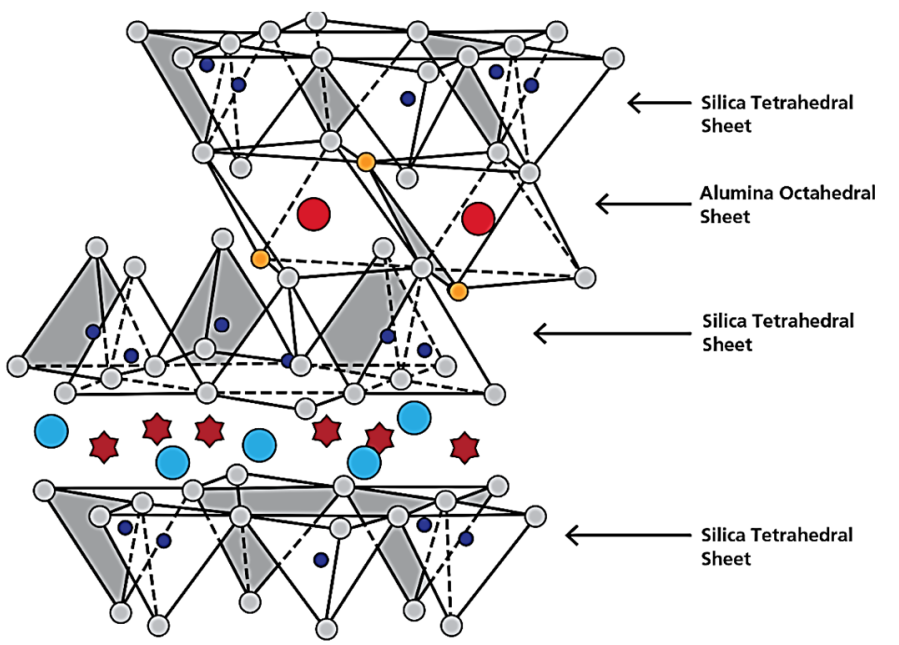

(a)

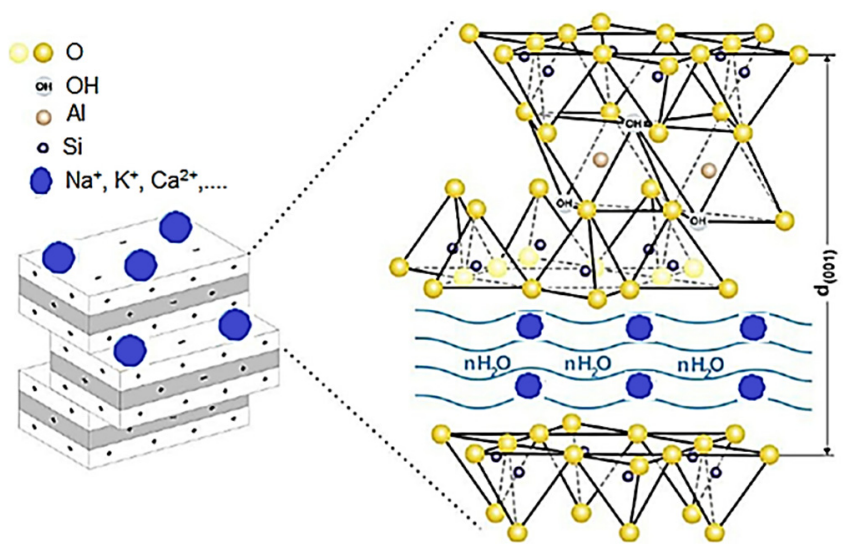

(b)

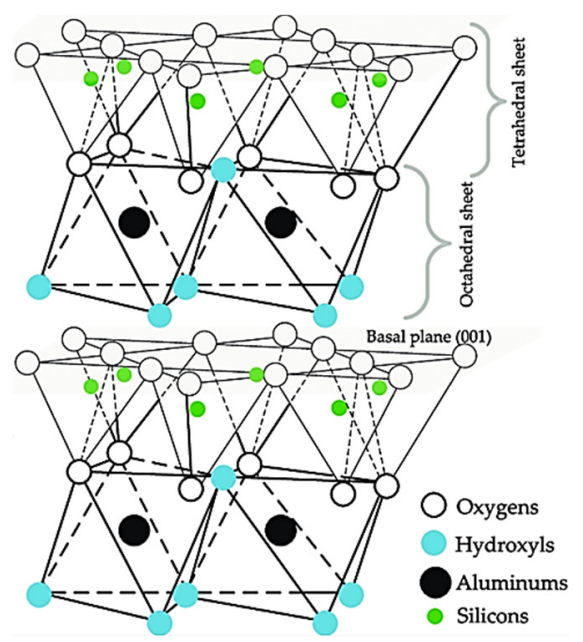

(c)

Figure 4. (a) Clay mineral structure [28]; (b) bentonite clay structure [29]; (c) kaolinite clay structure [30].

\section{Characteristics and Manufacturing Process of Some Industrial Waste}

Ground granulated blast furnace slag (GGBS) is an industrial by-product from the manufacturing of pig iron, during the production, the molten slag is cooled and solidified to a greasy state by rapid water quenching, where no air or little crystallisation occurs. This process results in the formation of sand size fragments with some flexible clinker-like materials known as GGBS. The chemical composition of the slag, its temperature at the time of water quenching and the method of production determines the physical structure and gradation of GGBS [31]. Silica fume is a by-product of silicon metal or ferrosilicon production in an electric furnace. The smoke generated from the furnace is collected and known as silica fume of micro silica. Silica fume is the most valuable by-product pozzolanic material due to its active and high pozzolanic properties [31]. Polypropylene fibre is produced by slurry solution or gas phase process where propylene monomers are subjected to heat and pressure in the presence of a catalyst system. Polypropylene is achieved at relatively low temperature and pressure yielding a translucent product known as polypropylene [32]. There are two varieties of glass fibre manufacturing: one involves the preparation of marble that is melted in the fibrilization stage and the other involves the direct melting route, where a furnace charges continuously with raw materials that are melted and refined as the glass reaches the forehearth above a set of platinumrhodium brushing from which the fibres are drawn. Rice husk is a by-product of rice 
milling commonly known as rice hull is the coating on the seed or grain of rice. It is formed from hard materials including silica and lignin to protect the seed during the growing season and can be used in soil stabilisation [33]. Metakaolin is one type of calcined clay, and it comes from the calcination of kaolin clay and has been explored as a partial substitute for cement [34]. Fly ash is a fine powder formed from the mineral matter in coal and consist of the non-combustible matter in coal and a small amount of carbon that remains from incomplete combustion. It is either cementitious or pozzolanic and can be used in soil stabilisation [35]. Particle size distribution of non-traditional stabiliser waste materials such as silica fume, metakaolin, rice husk ash and fly ash compared to traditional cement are shown in Figure 5. The manufacturing process and end product of GGBS, silica fume, polypropylene fibre and glass fibre are shown in Figure 6a-h. Some properties of waste materials used in soil stabilisation are shown in Table 7. Table 8 shows some mechanical properties of polypropylene fibre and Table 9 shows the main physical and chemical properties of plastic waste.

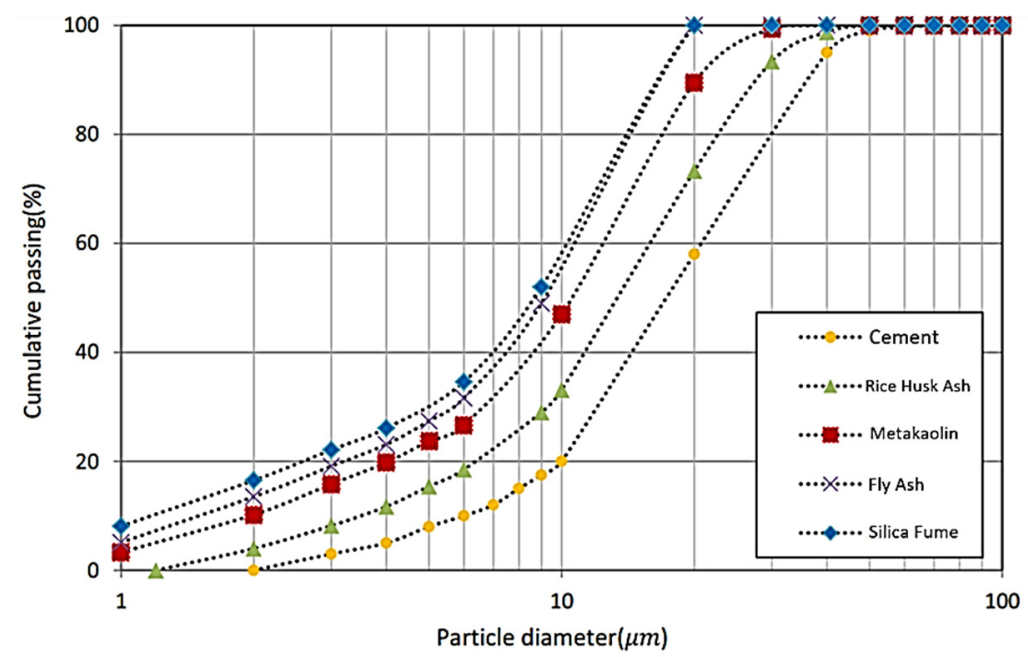

Figure 5. Particle size distribution curves of cement and pozzolanic materials [36].

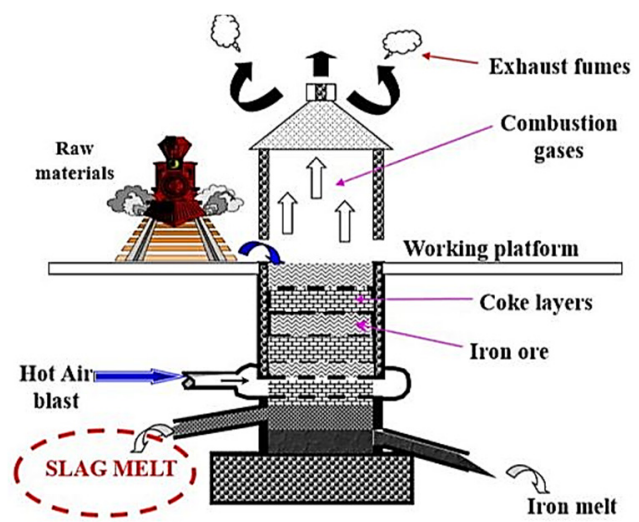

(a)

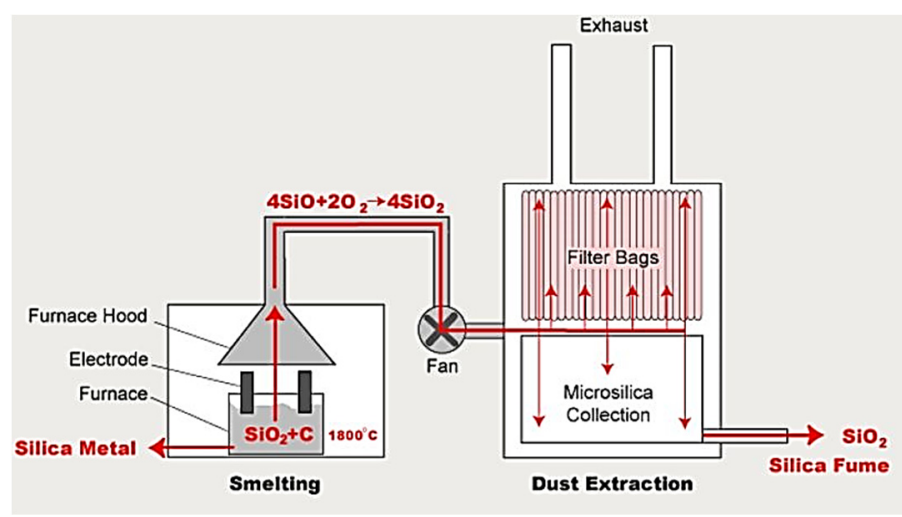

(b)

Figure 6. Cont. 


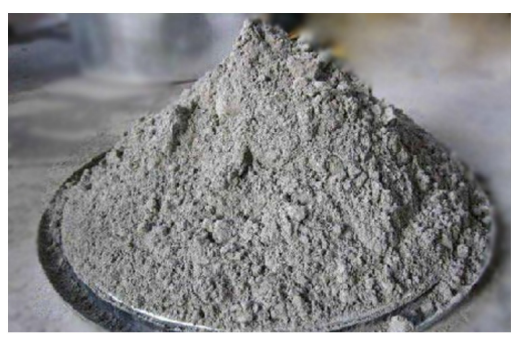

(c)

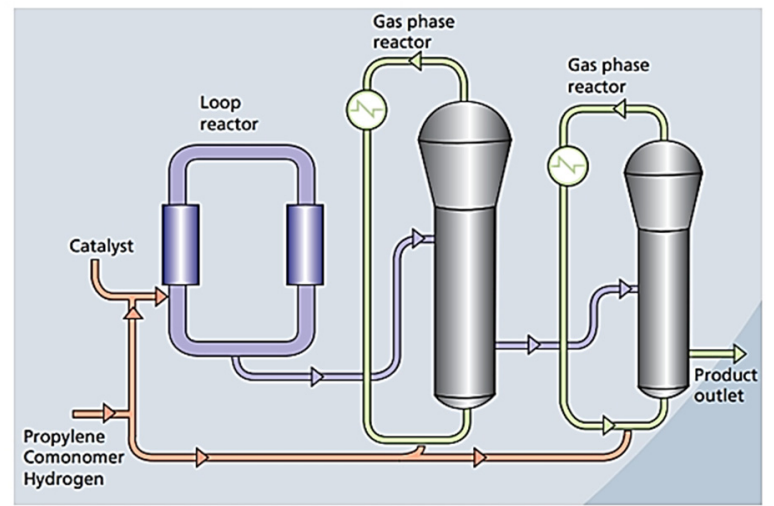

(e)

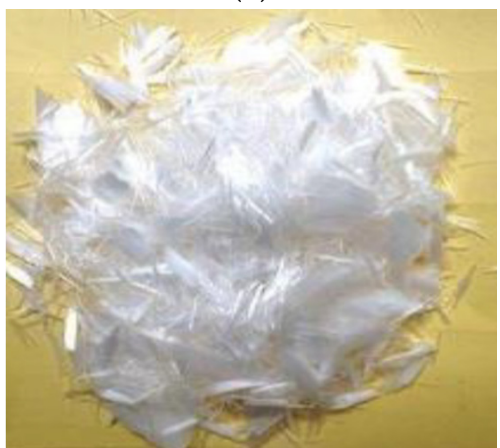

(g)

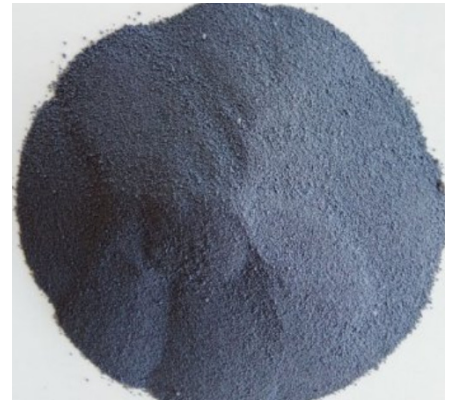

(d)

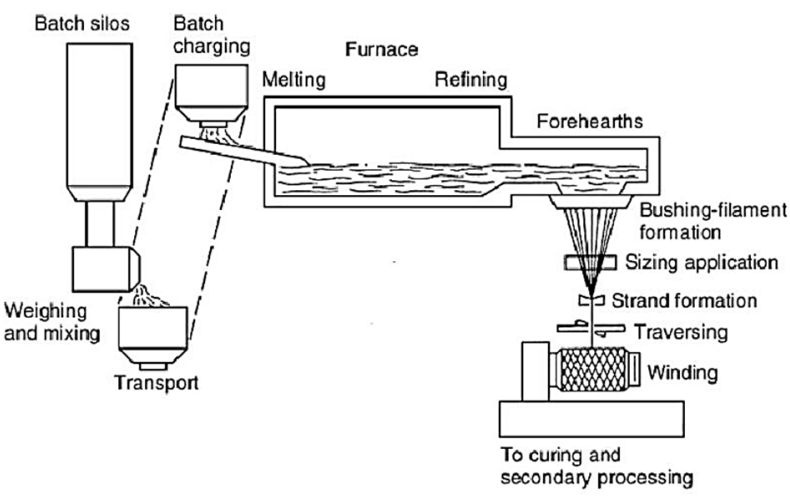

(f)

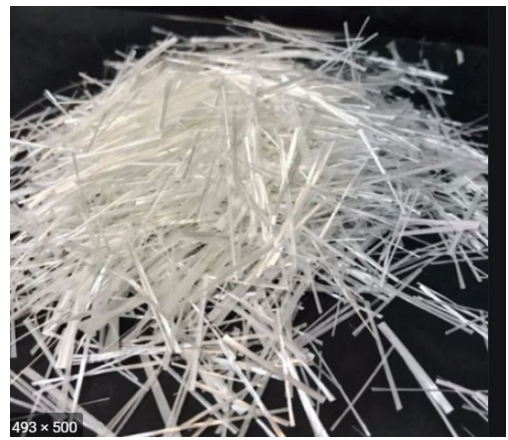

(h)

Figure 6. (a) Schematic diagram of the manufacturing process of GGBS [31]; (b) manufacturing process of silica fume [37]; (c) the end product of processed GGBS [38]; (d) the end product of processed silica fume [39]; (e) manufacturing process of polypropylene [40]; (f) schematics of marble melt process for glass fibre production [40]; (g) the end product of processed polypropylene fibre [41]; (h) the end product of processed glass fibre [42].

Table 7. Chemical composition mineralogy and physical properties of waste.

\begin{tabular}{cccccccccccc}
\hline Oxide & $\mathbf{S i O}_{\mathbf{2}}$ & $\mathbf{A l}_{\mathbf{2}} \mathbf{O}_{\mathbf{3}}$ & $\mathbf{F e}_{\mathbf{2}} \mathbf{O}_{\mathbf{3}}$ & $\mathbf{M g O}$ & $\mathbf{C a O}$ & $\mathbf{K}_{\mathbf{2}} \mathbf{O}$ & $\mathbf{S O}_{\mathbf{3}}$ & $\mathbf{T i O}_{\mathbf{2}}$ & $\mathbf{N a}_{\mathbf{2}} \mathbf{O}$ & Loss of Ignition & $\mathbf{S o u r c e}$ \\
\hline BDW & 52 & 41 & 0.7 & 0.12 & 4.32 & 0.53 & 0.33 & 0.65 & 0.05 & 2.01 & {$[43]$} \\
GGBS & 34.72 & 19.11 & 0.5 & 8.46 & 35.27 & 0.58 & 0.18 & 0.65 & 0.16 & - & {$[44]$} \\
Silica fume & 93.38 & 0.15 & 0.21 & 0.10 & 0.67 & - & 0.37 & - & - & 1.46 & {$[45]$} \\
Glass fibre & 45.47 & 12.11 & 1.04 & - & 38.49 & 0.94 & 0.43 & - & - & - & {$[46]$} \\
RHA (Malaysia) & 93.10 & 0.21 & 0.21 & 1.59 & 0.41 & 2.31 & - & - & - & 2.36 & {$[47]$} \\
RHA (Brazil) & 92.90 & 0.18 & 0.43 & 0.35 & 1.03 & 0.72 & 0.10 & - & 0,02 & - & {$[47]$} \\
RHA (Netherlands) & 86.90 & 0.84 & 0.73 & 0.57 & 1.40 & 2.46 & - & - & 0.11 & 5.14 & {$[47]$} \\
RHA (India) & 90.70 & 0.40 & 0.40 & 0.50 & 0.40 & 2.20 & 0.10 & - & 0.10 & 4.80 & {$[47]$} \\
\hline
\end{tabular}


Table 7. Cont

\begin{tabular}{cccccccccccc}
\hline Oxide & $\mathbf{S i O}_{\mathbf{2}}$ & $\mathbf{A l}_{\mathbf{2}} \mathbf{O}_{\mathbf{3}}$ & $\mathbf{F e}_{\mathbf{2}} \mathbf{O}_{\mathbf{3}}$ & $\mathbf{M g O}$ & $\mathbf{C a O}$ & $\mathbf{K}_{\mathbf{2}} \mathbf{O}$ & $\mathbf{S O}_{\mathbf{3}}$ & $\mathbf{T i O}_{\mathbf{2}}$ & $\mathbf{N a}_{\mathbf{2}} \mathbf{O}$ & Loss of Ignition & $\mathbf{S o u r c e}$ \\
\hline RHA (Iraq) & 86.80 & 0.40 & 0.19 & 0.37 & 1.40 & 3.84 & 1.54 & - & 1.15 & 3.30 & {$[47]$} \\
RHA (USA) & 94.50 & $\mathrm{Trace}$ & $\mathrm{Trace}$ & 0.23 & 0.25 & 1.10 & 1.13 & - & 0.78 & - & {$[47]$} \\
RHA (Canada) & 87.20 & 0.15 & 0.16 & 0.35 & 0.55 & 3.68 & 0.24 & - & 1.12 & 8.55 & {$[47]$} \\
Paper Sludge Ash & 60.57 & 2.06 & 0.92 & 3.59 & 14.94 & 0.16 & 1.07 & - & 0.22 & - & - \\
Fly ash & 48.28 & 27.72 & 7.19 & 2.51 & 10.51 & - & 3.16 & 1.28 & - & {$[48]$} \\
Boron & 21.64 & 0.75 & 0.19 & 9.40 & - & - & - & 16.77 & 7.88 & 35.38 & {$[49]$} \\
Marble dust & 0.2 & 0.07 & 0.11 & 0.3 & 54.5 & - & 0.08 & - & 0.01 & 44.52 & {$[49]$} \\
Granite dust & 89.30 & 0.19 & 0.23 & 0.46 & 0.58 & - & 0.06 & - & 0.37 & 8.26 & {$[49]$} \\
Green Bayburt Stone & 68.22 & 12.06 & 1.84 & 1.14 & 2.17 & 1.54 & 0.09 & - & 6.08 & 6.79 & {$[50]$} \\
\hline
\end{tabular}

Table 8. Mechanical properties of polypropylene fibre [51].

\begin{tabular}{cc}
\hline Properties & Description \\
\hline Tensile strength (gf/den) & $3.5-5.5$ \\
Elongation $(\%)$ & $40-100$ \\
Abrasion resistance & Good \\
Moisture absorption $(\%)$ & $0-0.05$ \\
Softening point $\left({ }^{\circ} \mathrm{C}\right)$ & 140 \\
Melting point $\left({ }^{\circ} \mathrm{C}\right)$ & 165 \\
Chemical resistance & General excellent \\
Relative density & 0.91 \\
Thermal conductivity & 6.0 (with air as 1.0) \\
Electric insulation & Excellent \\
Resistance to mildew and moth & Excellent \\
\hline
\end{tabular}

Table 9. Main physical and chemical properties of plastic waste [52].

\begin{tabular}{cc}
\hline Properties & Description \\
\hline $\mathrm{C}(\%)$ & 85.0 \\
$\mathrm{H}(\%)$ & 13.8 \\
$\mathrm{~N}(\%)$ & 0 \\
$\mathrm{~S}(\%)$ & 0 \\
$\mathrm{O}(\%)$ & 0 \\
Ashes $(\%)$ & 1.0 \\
Moisture $(\%)$ & 0.2 \\
Low heating value $(\mathrm{kJ} / \mathrm{kg})$ & 45,500 \\
Starting devolatilization temp $\left({ }^{\circ} \mathrm{C}\right)$ & $\approx 250$ \\
Devolatization Temp $\left({ }^{\circ} \mathrm{C}\right)$ & $\approx 410$ \\
Diameter and thickness of fuel pellets $(\mathrm{mm})$ & 5.2 \\
Particle density $\left(\mathrm{kg} / \mathrm{m}^{3}\right)$ & 940 \\
Bulk density $\left(\mathrm{kg} / \mathrm{m}^{3}\right)$ & 570 \\
\hline
\end{tabular}

\section{Production of Processed Waste and Their Utilisation in Road Subgrade}

Various kinds of waste materials are being generated worldwide as a result of human activities. Due to our inability to recycle all the waste society produces, a large section of these waste materials is dumped in landfills and others dumped in water bodies which have contributed to some of the environmental problems we face today. According to [53], the world generates 2.01 billion tonnes of municipal solid waste annually and it is expected to grow to 3.40 billion tonnes by 2050 Figure 7. In the approach to mitigate the problem, many strategies have been put in place including recycling incineration. However, these strategies are not enough to deal effectively with all the waste we produce. This has encouraged the use of processed waste in the engineering and construction sector for the construction of roads pavements and buildings. However, the availability of processed waste for use quantities and the environmental effect associated with waste processing 
has been questioned. The [54] stated that, a huge amount of processed waste is produced around the world for use in various engineering activities. Before waste materials can be used in subgrade stabilisation, the waste must first of all be processed to remove toxic chemicals and contamination to make them suitable for use as an additive in road construction. The use of processed waste in subgrade stabilisation is arguably the new trend in chemical stabilisation of subgrade materials. This is aimed at reducing the amount of greenhouse gas emissions and the environmental effects associated with cement and lime production. A huge amount of processed waste is produced around the world for use in various engineering activities. However, many concerns have been raised with regard to the cost and environmental effects associated with the production process of these waste materials. These concerns include the amount of $\mathrm{CO}_{2}$ emitted during waste processing and, are there enough processed waste available to meet the current demand for use in subgrade stabilisation?

Research has shown that there are enough processed industrial by-products and waste materials available to meet the current demands for soil stabilisation. The processing of these waste materials is cheaper and sustainable compared to the cost of cement and its production [55]. Over 20 million metric tonnes (22 million tonnes) of fly ash are used annually in a variety of engineering applications typically highway engineering [53]. Table 10 shows that 62 million metric tonnes (68 million tonnes) of fly ash was produced in 2001 and only 20 million metric tonnes (22 million tonnes) or 32\% of the total production was used. The total production of hypo-sludge in Bangladesh which is capable of replacing cement is equivalent to $550,000 \times 6=3,300,000 \mathrm{~kg}$ per year. A reduction in the amount of coal combustion products that must be disposed of in landfills has been observed due to their use in subgrade stabilisation [53]. The use of waste in soil stabilisation provides environmental and economic advantages [49]. Figure 7 shows projected waste generation, by region Mt per year. According to Figure 7, there has been a significant increase in the amount of waste generated by the various region since 2016 and it is projected to increase from 177 to $602 \mathrm{Mt}$ by the year 2030 and from 255 to $714 \mathrm{Mt}$ by the year 2050 respectively. Table 10 shows 61.84 million metric tonnes of fly ash was produced in 2001 and only 19.98 million metric tonnes were used $(32.3 \%)$. Table 11 shows the annual production of major industrial solid wastes generated in India which are not fully utilised. Figure $8 \mathrm{a}, \mathrm{b}$ shows the modes and utilisation of fly ash in various engineering sectors in India in the year 2014-2015, which includes the enhancement of the engineering properties of subgrade materials. Hence, there are no projections of waste shortage in the future by various statistics to hinder the reliance on the use of waste in subgrade stabilisation.

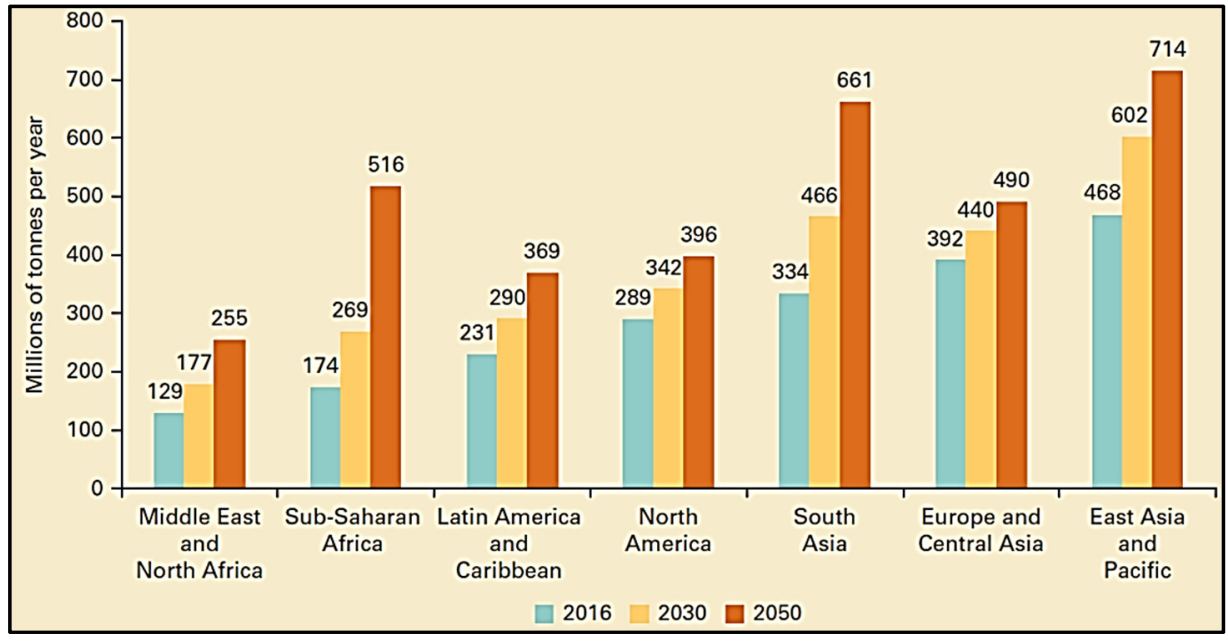

Figure 7. Projected waste generation, by region Mt per year [53]. 
Table 10. Fly ash production and use in the US in 2001 [53].

\begin{tabular}{cccc}
\hline & Million Metric Tonnes & Million Short Tonnes & Percent \\
\hline Produced & 61.84 & 68.12 & 100 \\
Used & 19.98 & 22.00 & 32.3 \\
\hline
\end{tabular}

Table 11. Major industrial solid wastes generated in India [56].

\begin{tabular}{ccccccccccc}
\hline Solid Waste & $\begin{array}{c}\text { Fly } \\
\text { Ash }\end{array}$ & GGBS & $\begin{array}{c}\text { Steel } \\
\text { Slag }\end{array}$ & $\begin{array}{c}\text { Red } \\
\text { Mud }\end{array}$ & $\begin{array}{c}\text { Lime } \\
\text { Sludge }\end{array}$ & $\begin{array}{c}\text { Lead-Zinc } \\
\text { Slag }\end{array}$ & $\begin{array}{c}\text { Phosphorus } \\
\text { Furnace Slag }\end{array}$ & PG & Jarosite & Kimberlite \\
Rejects
\end{tabular}

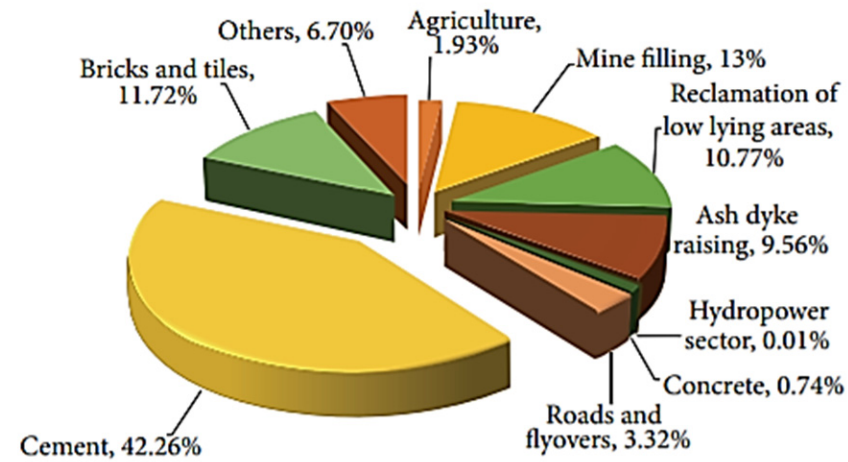

(a)

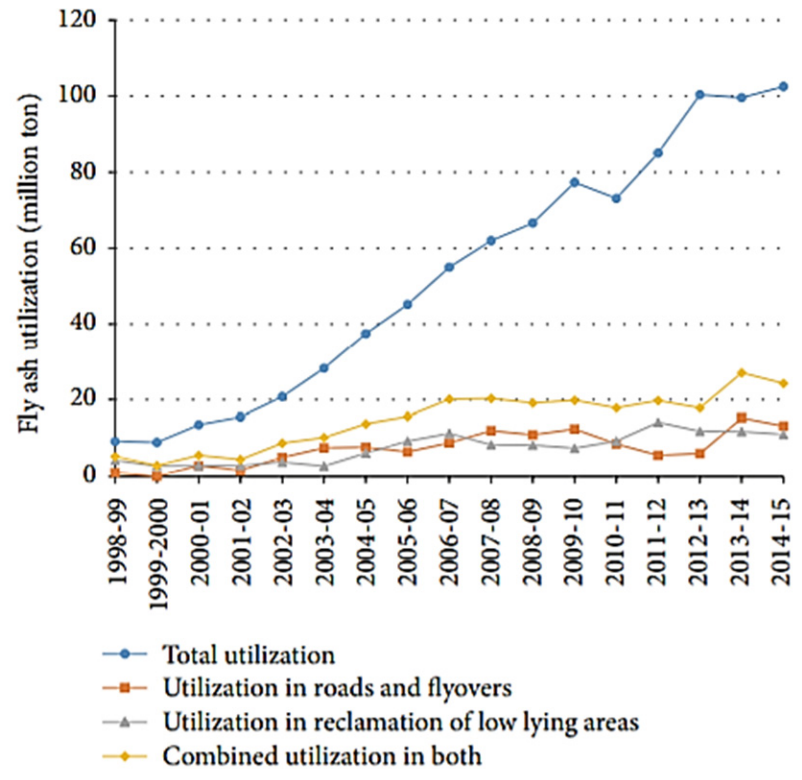

(b)

Figure 8. (a) Modes of the utilisation of fly ash in the years 2014-2015 [57]; (b) utilisation of Fly ash in areas of engineering [56].

According to the [57] report, about 1.3 billion tonnes of solid waste are generated by cities globally each year and the volume is expected to increase to about 2.2 billion tonnes by 2025 [58]. Statistics have shown that approximately 780 million tonnes of waste are generated worldwide. These wastes include coal combustion products (CCP) such as fly ash, bottom ash, cenospheres, conditioned ash and flue gas desulphurisation gypsum. Out of these, the largest CCP of 395 million tonnes were produced by China, 118 million tonnes by North America, 105 million tonnes by India, 52.6 million tonnes by Europe, 31.1 million tonnes by Africa and a minor contribution from the Middle East [59]. Table 12 shows CCP production around the world. According to [60], approximately 400 million tonnes of GGBS are produced annually worldwide whiles the production of steel slag is around 350 million tonnes. Studies have shown that an estimated amount of 70-120 million tonnes per year of red mud is produced worldwide [61], while an estimated 100-280 million tonnes of phosphogypsum is produced every year [62]. Cement kiln dust of approximately 510-680 million tonnes is produced yearly [63]. India had a fly ash production of about 163.56 million tonnes per year in 2014 which increased to 184.14 million tonnes in 2014 [57]. Meanwhile, the utilisation of fly ash in the tear 2012-2013 in India was 100.37 million tonnes which are approximately $61.37 \%$ of the total waste produced that year [64]. About 
$41.18 \%$ of fly ash was utilised by cement the cement industry in India whiles $11.78 \%$ and $6 \%$ fly ash was utilised for reclamation of low-lying areas and as fill for road embankments. Table 13 shows some other industrial waste produces in India and Figure 9 shows modes of fly ash utilisation in India from 2012-2013.

Table 12. CCP production around the world [59].

\begin{tabular}{|c|c|c|c|c|c|}
\hline Country/Region & $\begin{array}{c}\text { CCP Production } \\
\text { (Mt) }\end{array}$ & CCP Utilisation (Mt) & $\begin{array}{c}\text { Utilisation Rate } \\
(\%)\end{array}$ & $\begin{array}{c}\mathrm{CCP} \\
\text { Production/Person } \\
(\mathrm{Mt})\end{array}$ & $\begin{array}{c}\text { CCP } \\
\text { Utilisation/Person } \\
\text { (Mt) }\end{array}$ \\
\hline Australia & 13.1 & 6.0 & 45.8 & 0.60 & 0.27 \\
\hline Canada & 6.8 & 2.3 & 33.8 & 0.20 & 0.07 \\
\hline China & 395 & 265 & 67.1 & 0.20 & 0.20 \\
\hline Europe & 52.6 & 47.8 & 90.9 & 0.11 & 0.10 \\
\hline India & 105 & 14.5 & 13.8 & 0.09 & 0.01 \\
\hline Japan & 11.1 & 10.7 & 96.4 & 0.09 & 0.08 \\
\hline $\begin{array}{l}\text { Middle East and } \\
\text { Africa }\end{array}$ & 32.2 & 3.4 & 10.6 & 0.02 & 0.01 \\
\hline United States & 118 & 49.7 & 42.1 & 0.37 & 0.16 \\
\hline Other Asia & 16.7 & 11.1 & 66.5 & 0.05 & 0.03 \\
\hline Russian Federation & 26.6 & 5.0 & 18.8 & 0.19 & 0.04 \\
\hline
\end{tabular}

Table 13. Summary of findings of improved engineering properties of subgrade using waste.

\begin{tabular}{|c|c|c|c|c|c|}
\hline Waste Type & Content (\%)/Ratio & Information Source & Test & $\begin{array}{l}\text { Results: UCS }\left(\mathrm{kN} / \mathrm{m}^{2}\right) \text {, } \\
\text { CBR (\%), Swell (mm), } \\
\text { Shrinkage }(\%)\end{array}$ & Standards \\
\hline Brick dust & $30-50$ & [65] & $\begin{array}{l}\text { CBR and UCS } \\
\text { increased }\end{array}$ & $\mathrm{CBR}=19 \& \mathrm{UCS}=20$ & ASTM D1883-16 \\
\hline $\begin{array}{l}\text { Brick dust } \\
\text { Brick dust } \\
\text { Brick dust }\end{array}$ & $\begin{array}{c}30-50 \\
0-16 \\
10-30\end{array}$ & $\begin{array}{l}{[66]} \\
{[67]} \\
{[68]}\end{array}$ & $\begin{array}{l}\text { Shrinkage reduced } \\
\text { CBR increased } \\
\text { CBR increased }\end{array}$ & $\begin{array}{c}\text { Shrinkage }=23.7 \text { to } 7.3 \\
\text { CBR }=7.9 \\
\text { CBR }=4.6\end{array}$ & $\begin{array}{l}\text { IS } 2720 \\
\text { ASTM D1883-16 } \\
\text { BS1377 }\end{array}$ \\
\hline Brick dust & $5-25$ & [69] & $\begin{array}{l}\text { UCS and CBR } \\
\text { increased }\end{array}$ & $\mathrm{UCS}=3544 \& \mathrm{CBR}=21.90$ & IS:2720 part 16 \\
\hline Brick dust & $0-30$ & [70] & $\begin{array}{l}\text { UCS increased \& } \\
\text { swell decreased }\end{array}$ & $\begin{array}{c}\text { UCS }=297.76 \& \text { Swell }= \\
23.98\end{array}$ & IS:2720 Part X1991 \\
\hline Brick dust & $10-50$ & [71] & $\begin{array}{l}\text { Swell reduced \&CBR } \\
\text { increased }\end{array}$ & Sewll $=0 \&$ CBR $=12.54$ & IS 2720 \\
\hline $\begin{array}{l}\text { Brick dust } \\
\text { Brick dust } \\
\text { Brick dust } \\
\text { Brick dust } \\
\text { Brick dust } \\
\text { Brick dust }\end{array}$ & $\begin{array}{l}10-30 \\
30-50 \\
10-40 \\
10-20 \\
10-20 \\
10-20\end{array}$ & $\begin{array}{l}{[72]} \\
{[73]} \\
{[74]} \\
{[75]} \\
{[75]} \\
{[75]}\end{array}$ & $\begin{array}{l}\text { CBR increased } \\
\text { CBR improved from } \\
\text { UCS improved } \\
\text { UCS improved } \\
\text { CBR improved } \\
\text { Swell decreased }\end{array}$ & $\begin{array}{c}\mathrm{CBR}=7.4 \\
\mathrm{CBR}=1.6 \text { to } 6.8 \\
\mathrm{UCS}=197 \\
\mathrm{UCS}=142.2 \\
\mathrm{CBR}=2.86 \\
\text { Swell }=0.83\end{array}$ & $\begin{array}{c}\text { IS:2720 part } 16 \\
\text { IS:2720 Part } 16 \\
\text { IS:2720 Part } 16 \\
\text { IS:2720 Part 16 } \\
\text { ASTM D1883-16 } \\
\text { 1977STM D1883-16 }\end{array}$ \\
\hline Brick dust & $10-20$ & [75] & $\begin{array}{l}\text { Shear strength } \\
\text { improved }\end{array}$ & $\mathrm{UCS}=67.15$ & BS 1377-1:2016 \\
\hline $\begin{array}{l}\text { GGBS } \\
\text { GGBS } \\
\text { GGBS } \\
\text { GGBS } \\
\text { GGBS }\end{array}$ & $\begin{array}{c}5-10 \\
70 \text { ratio } \\
0-30 \\
0-30 \\
3-9\end{array}$ & $\begin{array}{l}{[76]} \\
{[77]} \\
{[78]} \\
{[79]} \\
{[80]}\end{array}$ & $\begin{array}{l}\text { UCS increased with } \\
\text { UCS increased } \\
\text { CBR increased } \\
\text { UCS increased } \\
\text { CBR increased }\end{array}$ & $\begin{array}{c}5 \% \text { and } 10 \% \text { GGBS } \\
\text { UCS }=450 \\
\text { CBR }=2.69 \\
\text { UCS }=263.5 \\
\text { CBR }=2.05 \text { to } 8.29\end{array}$ & $\begin{array}{c}\text { IS: } 4332 \text { Part } 5 \text { [1970] } \\
\text { IS:2720 Part 16 } \\
\text { IS:2720 Part 10-1991 } \\
\text { IS:2720 Part 16 } \\
\text { IS:2720 Part } \\
\text { 40-1977STM } \\
\text { D1883-16 }\end{array}$ \\
\hline $\begin{array}{c}\text { GGBS } \\
\text { Plastic waste }\end{array}$ & $\begin{array}{c}3-12 \\
0.0-1.0\end{array}$ & $\begin{array}{l}{[80]} \\
{[81]}\end{array}$ & $\begin{array}{l}\text { Swell reduced } \\
\text { CBR values increased }\end{array}$ & $\begin{array}{c}\text { Swell }=67 \text { and } 21 \\
\text { CBR }=1.967 \text { to } 2.479\end{array}$ & $\begin{array}{l}\text { IS:2720 Part } 16 \\
\text { IS-2720: Part } 7\end{array}$ \\
\hline Plastic waste & $0-1.5$ & [82] & $\begin{array}{l}\text { UCS and CBR } \\
\text { increased }\end{array}$ & $\mathrm{UCS}=40$ and $\mathrm{CBR}=2.35$ & IS:2720 Part 16 \\
\hline $\begin{array}{l}\text { Polypropylene } \\
\text { Polypropylene }\end{array}$ & $\begin{array}{c}0.5-2 \\
0.05-0.25\end{array}$ & $\begin{array}{l}{[78]} \\
{[83]}\end{array}$ & $\begin{array}{l}\text { CBR increased } \\
\text { UCS increased }\end{array}$ & $\begin{array}{l}\mathrm{CBR}=8.51 \\
\mathrm{UCS}=1280\end{array}$ & $\begin{array}{c}\text { IS } 2720 \text { part } 10 \\
\text { IS:2720 Part } 40-1977\end{array}$ \\
\hline Polypropylene & $0.2-0.5$ & [84] & $\begin{array}{l}\text { Swell reduced } \\
\text { considerably }\end{array}$ & Swell $=21.73$ & IS:2720 Part 40-1977 \\
\hline Polypropylene & $0.5-2$ & [85] & $\begin{array}{l}\text { Swell pressure } \\
\text { reduced }\end{array}$ & Swell $=110$ to 59 & IS 2720 part 10 \\
\hline $\begin{array}{l}\text { Polypropylene } \\
\text { Polypropylene } \\
\text { Polypropylene }\end{array}$ & $\begin{array}{c}0.1-1.3 \\
0-1.4 \\
0.05-0.30\end{array}$ & $\begin{array}{l}{[39]} \\
{[86]} \\
{[87]}\end{array}$ & $\begin{array}{l}\text { UCS increased } \\
\text { UCS increased by } \\
\text { UCS decreased }\end{array}$ & $\begin{array}{c}\mathrm{USC}=338.7 \\
\mathrm{UCS}=29.87 \\
\mathrm{UCS}=600 \text { to } 330\end{array}$ & $\begin{array}{l}\text { IS:4332 Part } 5 \text { [1970] } \\
\text { IS:4332 Part } 5 \text { [1970] }\end{array}$ \\
\hline
\end{tabular}




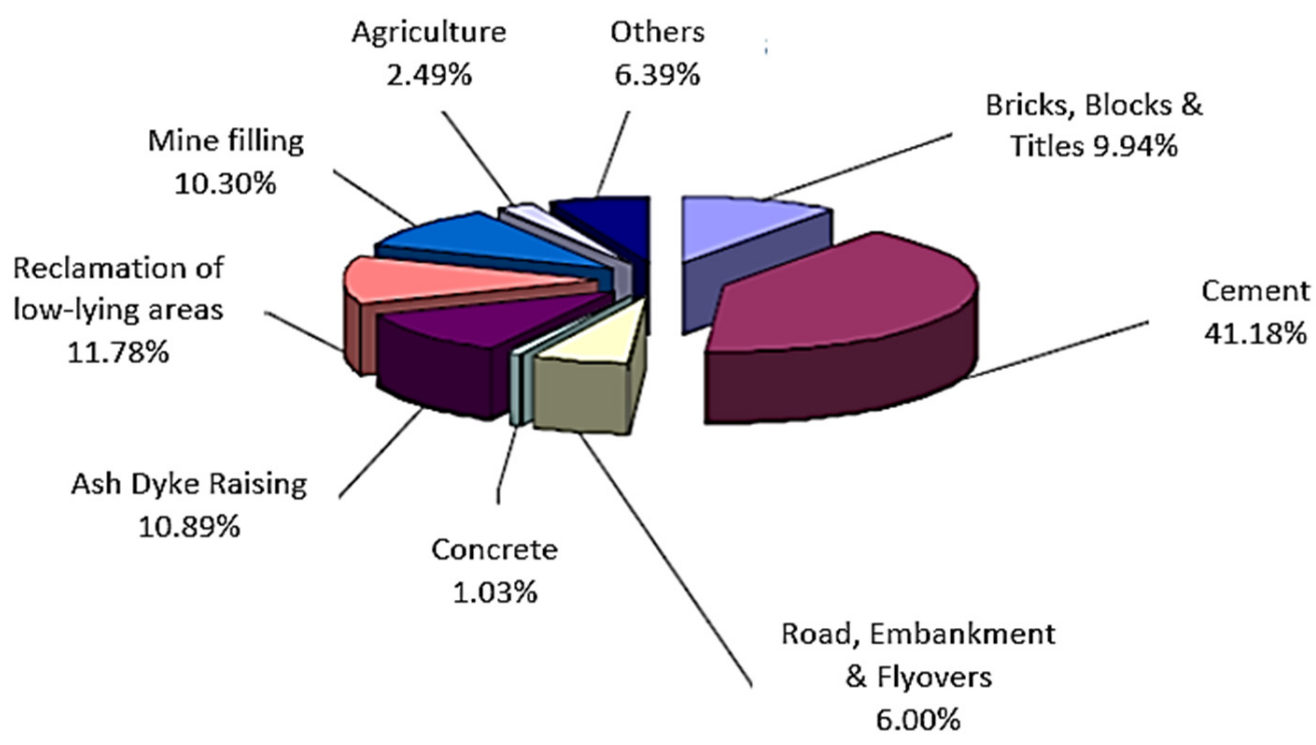

Figure 9. Modes of fly ash utilisation in 2012-2013 [64].

\section{Sustainability of Using Processed Waste in Subgrade Stabilisation}

Climate change has been a huge challenge to the world and many efforts have been made to remedy the situation by ensuring a more sustainable way of production especially in the construction sector to reduce greenhouse gas emissions [88]. Cement and lime are mostly used in subgrade stabilisation. However, there are many environmental effects associated with the production of cement and lime. The lime-drying process produces the biggest carbon emission ( $962.1 \mathrm{skg} \mathrm{CO}$-eq/t sludge) accounting for $89.0 \%$ of the total emission [89]. According to [90], $7 \%$ of the world's $\mathrm{CO}_{2}$ emission comes from cement production this is due to the high demand for cement. One tonne of $\mathrm{CO}_{2}$ is emitted for every ton of cement produced. During cement production, $50 \%$ of the carbon emitted as a result of the calcination of the raw materials and $50 \%$ of the energy used [91]. Recent studies have shown the efforts made by many countries to mitigate carbon emissions in cement plants. However, the problem of greenhouse gas emission persists and the total replacement of cement with processed waste materials can help mitigate the problem and reduce the associated environmental problems.

Some concerns have been raised on the production of processed wastes including their associated environmental effects such as $\mathrm{CO}_{2}$ emission and high energy consumption. However, the environmental impact associated with the production of processed waste is far less compared to the problems associated with the use of cement and its production. Using GGBS in high volumes as supplementary cementitious materials is good from the environmental point of view [92]. The higher the amount of GGBS used in replacing cement in soil stabilisation the lesser carbon footprint is expected due to the reduction in the use of cement [92]. The use of processed waste such as fly ash has significant environmental benefits including a net reduction in energy use and greenhouse gas emission. Figure 10 shows the contribution of the top ten countries in global $\mathrm{CO}_{2}$ emission in 2008. 


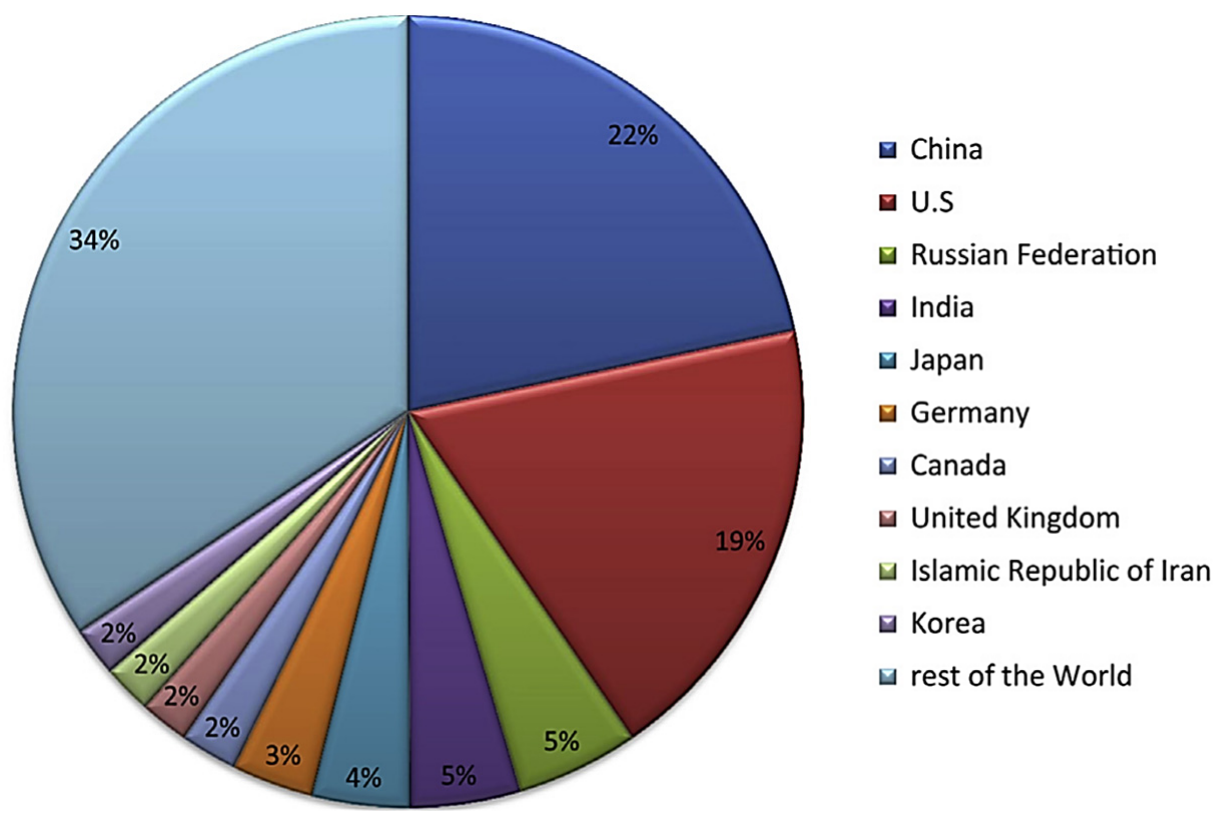

Figure 10. Contribution of the top 10 countries in global $\mathrm{CO}_{2}$ emission in 2008 [93].

\section{Effect of Process Waste on the Engineering Properties of Road Subgrade}

Brick dust waste is mainly sourced from the cutting and demolition of brick and brick structures. Brick dust waste has been reportedly used in various studies to stabilise expansive road subgrade material. According to [94], the California bearing ratio (CBR) value increased to over $400 \%$ and a high unconfined compressive strength (UCS) was achieved when an optimum brick dust waste (BDW) content of $40 \%$ was used during expansive subgrade stabilisation. Compressive strength and CBR of soil reached their maximum values based on the standard compaction test when an optimum content of $40 \%$ BDW was used in subgrade stabilisation in accordance with ASTM D2166/D2166M-13 and ASTM D1883-14.

Other studies have shown an increase in CBR values at optimum BDW content from $5 \%$ to $20 \%$ [95]. The best stabilisation effects were obtained with brick dust waste at an optimum content of 50\% [96]. A reduction in swell linear shrinkage and compaction water content was recorded when an optimum content of $50 \%$ brick dust waste was used in subgrade stabilisation [65]. Good CBR and swelling results were achieved when $20 \%$ of brick dust waste proportions were used in expansive subgrade stabilisation for flexible pavement [97]. Unconfined compressive strength increased with the addition of 30\% brick dust waste and began to decrease at $40 \%$ brick waste in accordance with ASTM D2166/D2166M-13 [74]. Studies under the use of brick waste as a partial replacement for cement in expansive subgrade stabilisation have shown that the optimum or the highest proportion of brick waste used in subgrade stabilisation to achieve good engineering properties of soil is up to $50 \%$. Brick dust waste proportion from $5 \%, 10 \%, 15 \%, 20 \%$ and $25 \%$ was used in subgrade stabilisation and the results obtained are as follows CBR 7.36, $8.54,13.70,19,13$ and 7.36. UCS $0.60,2.60,4.31$ and $2.84 \mathrm{~kg} / \mathrm{cm}^{2}$ respectively. Unconfined compressive strength increased with the addition of $30 \%$ brick dust waste and began to decrease at $40 \%$ brick waste [74].

GGBS is a by-product of the steel manufacturing process and has been successfully used in various studies as cement replacement to stabilise expansive road subgrade material. The first application of GGBS based stabiliser combination in road pavement construction in the UK was on the A421 Tingwick Bypass in Buckinghamshire, and on the A130 road near London [98]. The engineering properties of expansive soil was improved with the addition of up to $7.5 \%$ GGBS [99]. Subgrade materials were stabilised with 16\% GGBS and the results obtained shows an increase in UCS value over time to $1500 \mathrm{kN} / \mathrm{m}^{2}$ in 
accordance with ASTM 1633 [100]. The addition of 6\% GGBS to a lime treated soil reduced swell from $8 \%$ to $0 \%$ [101]. High compressive strength of 14.2, 89, 211.9 and $656 \mathrm{kPa}$ was achieved when GGBS proportions of $6 \%, 12 \%, 18 \%$ and $24 \%$ were used in subgrade stabilisation after 28 days of curing [102]. Plastic waste has been successfully used in various studies as an additive to stabilise expansive road subgrade material. CBR value of 3.04 was achieved for soil stabilised with up to $2 \%$ plastic strip and UCS values of up to $316.4 \mathrm{kN}$ were achieved [103]. Synthetic fibres such as polypropylene have been reportedly used in various studies as an additive to stabilise expansive road subgrade material. Plastic waste has been successfully used in various studies as an additive to stabilise expansive road subgrade material. CBR value of 3.04 was achieved for soil stabilised with up to $2 \%$ plastic strip and UCS values of up to $316.4 \mathrm{kN}$ were achieved [103]. Synthetic fibres such as polypropylene have been reportedly used in various studies as an additive to stabilise expansive road subgrade material. Figure 11a shows the effect of polypropylene fibre on UCS; Figure 11b shows the UCS results of polypropylene fibre content, and Figure 11c shows the effect of brick dust waste on CBR. Table 13 shows a summary of findings of improved engineering properties of expansive subgrade stabilised using various types of processed waste.

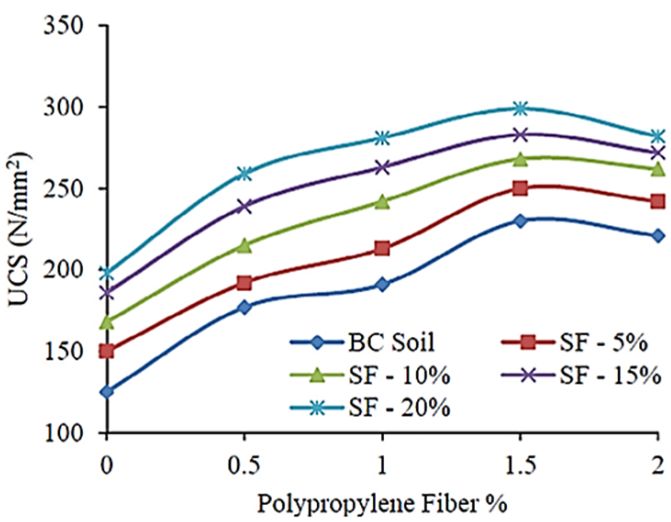

(a)

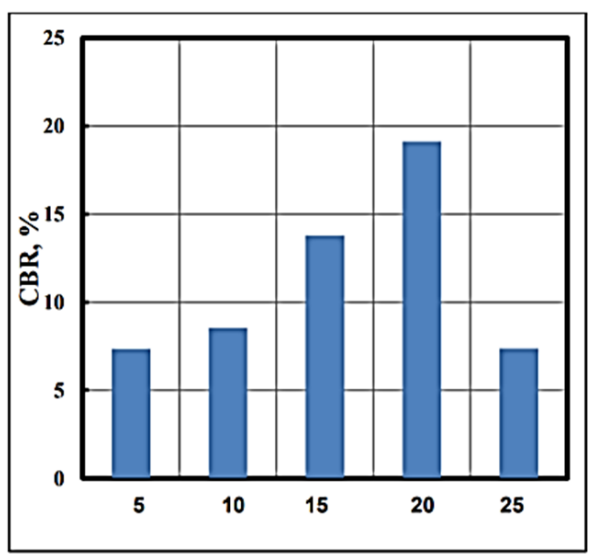

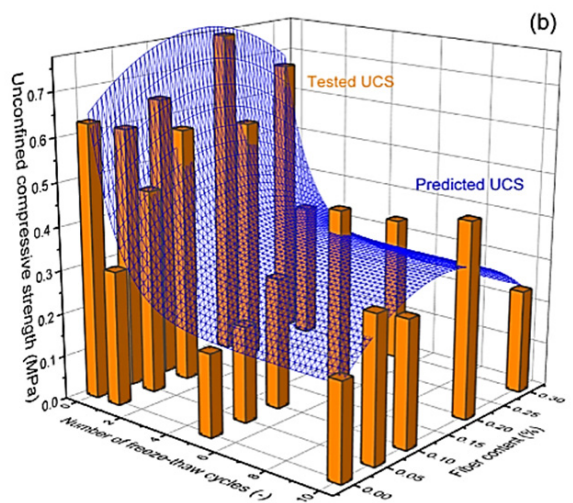

(b)

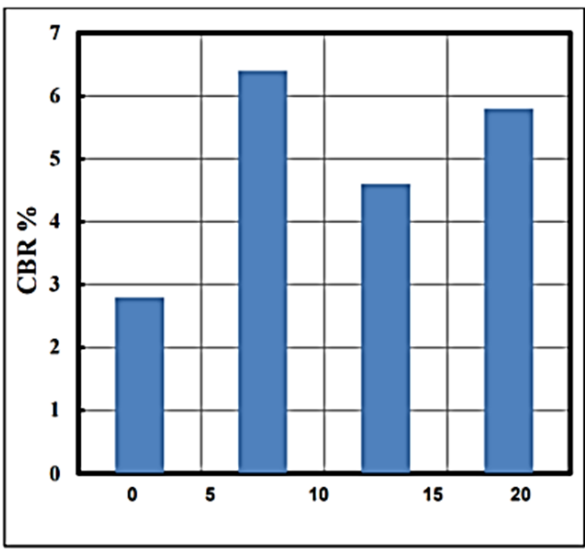

(c)

Figure 11. (a) Effect of polypropylene fibre on UCS [39]; (b) UCS results of poly-propylene fibre content [66] and (c) Effect of Brick dust waste on CBR [95].

\section{Enhancement Mechanisms of Waste, Cement and Lime in Subgrade Stabilisation 8.1. Lime}

Before cement, quick lime or hydraulic lime was the most common lime used in subgrade stabilisation. It has proven to be a good modification agent for the stabilisation of highway and airport pavement subgrade. When the soil is mixed with lime, a lime-soil 
reaction takes place which may change the moisture and density relationship of the soil. The addition of lime as a binder to soil triggers a lime hydration process responsible for $\mathrm{pH}$ increase in soil. The lime hydration process with the aid of calcium, release cementitious products (calcium-silicate-hydrate $(\mathrm{C}-\mathrm{S}-\mathrm{H})$ and calcium-aluminate-hydrate $(\mathrm{C}-\mathrm{A}-\mathrm{H})$ ) responsible for soil stabilisation. When lime is mixed with pozzolanic materials such as fly ash, a pozzolanic reaction takes place which releases cementitious products C-S$\mathrm{H}$ and $\mathrm{C}-\mathrm{A}-\mathrm{H}$ gel. Pozzolanic materials are any material with the ability to react with calcium hydroxide to produce $\mathrm{C}-\mathrm{S}-\mathrm{H}$ and $\mathrm{C}-\mathrm{A}-\mathrm{H}$ gel. Pozzolanic reaction is the process where cement-like compounds are formed between lime and certain clay materials to bind soil particles together. This reaction further increases the strength and durability of stabilised subgrade depend on curing time and temperature [104]. Lime works well with clay minerals in soil with plasticity greater than $10 \%$ and a minimum clay content of $10 \%$. A soil with a plasticity index between $20 \%$ and $30 \%$ with a liquid limit from $25 \%$ to $50 \%$ is recommended for lime stabilisation in most civil engineering applications [105]. Unlike cement, lime is slow in achieving its strength resulting in a long curing time. Long-term stabilisation effects are generated as a result of pozzolanic reactions which occur depending on the characteristics of the soil being treated.

\subsection{Cement}

Portland cement is a common subgrade stabilisation material used to improve the engineering properties of subgrade materials. It is a finely ground powder (hydraulic binder) that becomes solid when mixed with water through the process called hydration [106]. During the hydration process cement gel matrix is produced (C-S-H) which binds the soil particles together and is responsible for strength gain [107]. In subgrade stabilisation, the amount of cement used is in the range of $4 \%$ and $15 \%$ to increase the strength of subgrade materials [108]. According to [109], cement is suitable for the stabilisation of subgrade with a low plasticity index ranging between $2 \%$ and $30 \%$. Additionally, a high $\mathrm{pH}$ can be recorded during cement hydration and $\mathrm{C}-\mathrm{S}-\mathrm{H}$ production as alkalis become solubilised due to pozzolanic reactions [110]. Figure 12a shows the pozzolanic reaction between clay particles and binder Figure 12b shows cementitious hydration activity between clay particles and binder.

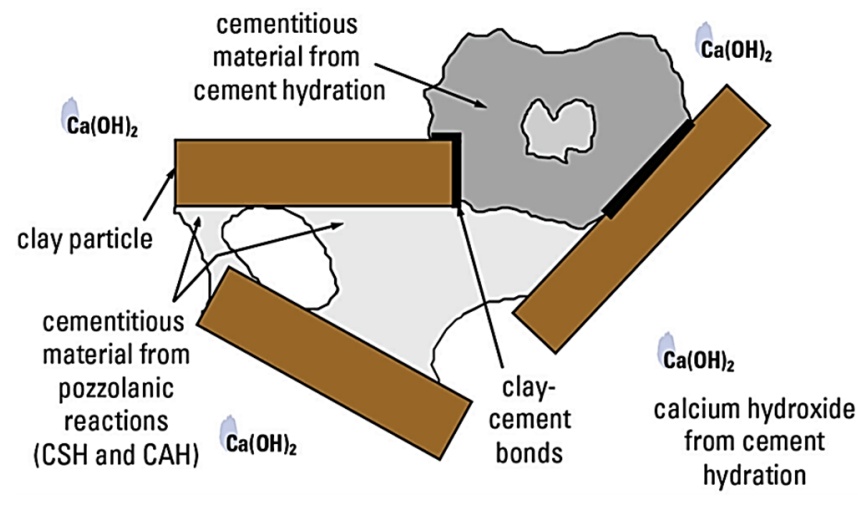

(a)

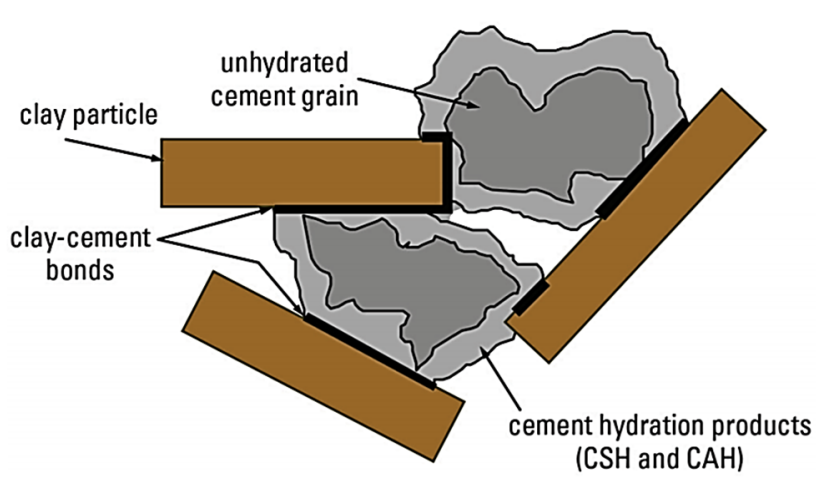

(b)

Figure 12. (a) Pozzolanic reaction between clay particles and binder [111]; (b) cementitious hydration activity between clay particles and binder [111].

\subsection{Waste Materials}

Any waste materials which possess pozzolanic properties has the ability to enhance the engineering properties of subgrade materials just like cement and lime. Waste materials are mostly used as a partial replacement for cement and lime for high strength gain and durability. The following pozzolanic waste materials reacts the same way as cement and 
lime when used in subgrade stabilisation; fly ash, GGBS, silica fume, rice husk ash, phosphogypsum, ceramic wastes, and construction and demolition waste based on pozzolanic materials. GGBS is a latent hydraulic binder when rapidly quenched in water at the molten stage [112]. GGBS forms a supplementary binder in many cement applications to enhance durability. In subgrade stabilisation, the addition of GGBS introduces additional alumina, calcia, silica and magnesia to the system [113]. Construction and demolition waste such as brick dust are produced by the calcination of alumina-silicate clay which are ground into fines powder giving it pozzolanic properties and can be used as cement replacement in subgrade stabilisation [114]. Brick waste is pozzolanic, materials that contain alumina/silica which react to form new compounds (calcium silicate hydrate $(\mathrm{C}-\mathrm{S}-\mathrm{H})$ and calcium aluminate hydrate $(\mathrm{C}-\mathrm{A}-\mathrm{H})$. The addition of pozzolanic waste materials to a soil mix will enhance the engineering properties and speedup setting time with increased strength and durability. Rice husk ash and silica fume are rich in amorphous $\mathrm{SiO}_{2}$ which have great pozzolanic properties [115]. Phosphogypsum has been used together with cement lime and fly ash to stabilise soil despite its high sulfate content [115]. Ceramic wastes possess pozzolanic properties because they are produced from clay and the thermal process leaves the $\mathrm{Al}$ and $\mathrm{Si}$ oxides in an amorphous state [115].

As much as partial replacement of cement and lime is important in the fight to reduce greenhouse gas emissions, the total replacement of cement and lime in subgrade stabilisation would speed up the global fight towards zero carbon. Recently, geopolymers have been used as cement replacement in subgrade stabilisation, providing an avenue for the total replacement of cement. The name "geopolymer" was coined by Davidovits, the inventor and developer of polymerisation to classify the newly discovered geosynthetic that produces inorganic polymeric materials now used in several industrial applications [116]. Geopolymers can be produced using waste materials such as fly ash, slag, silica fume, bentonite etc. amongst these waste materials, fly ash-based geopolymer cementitious binder has emerged as a promising new cement alternative in road subgrade stabilisation [117]. Fly ash-based geopolymers are produced by the chemical reaction of aluminosilicate oxides $\left(\mathrm{Si}_{2} \mathrm{O}_{5}, \mathrm{Al}_{2} \mathrm{O}_{2}\right)$ with alkali polysilicates yielding polymeric $\mathrm{Si}-\mathrm{O}-\mathrm{Al}$ bonds. Geopolymer can be produced with any waste materials containing silica, alumina and calcium content-rich composition. Preferably, low-calcium fly ash should be used than high calcium (ASTM class C) fly ash for the formation of geopolymers. This is because the presence of a high amount of calcium may affect the polymerisation process [118]. Fly ash with sodium hydroxide and sodium silicate as well as potassium hydroxide with potassium silicate combinations was used to produce geopolymer [119]. The presence of calcium content in fly ash significantly improved compressive strength development during subgrade stabilisation in a short curing time [120]. Using polymers in road subgrade stabilisation improves the density and load-bearing capacity of the pavement subgrade [2].

\section{Limitations in the Use of Waste Compared to Cement and Lime in Subgrade Stabilisation}

The use of waste as additives in subgrade stabilisation comes with some limitations that need to be addressed. Some of these limitations include contamination through the leaching of toxic substances into waste dumped in landfills. The engineering properties and performance of road subgrade can be affected due to these toxic materials found in the waste. Additionally, the cost-effectiveness of decontaminating these wastes can be a limitation to the use of waste materials in subgrade stabilisation. Many times, greenhouse gas emissions are associated with the production of cement and lime. However, there is a significant amount of carbon dioxide emission associated with the processing of waste materials for use as additives in subgrade stabilisation. Even though the processing of waste materials and cement and lime production produce some amount of carbon dioxide, the low cost of waste materials used in subgrade stabilisation holds promising keys to a sustainable future. 


\section{Summary of Findings and Future Focus}

The effects of expansive subgrade materials in road pavement structure and the damage they cause to road pavement and other infrastructure has been reviewed. The study has shown that the problem of expansive subgrade is not limited to one geographical location, and the damage caused by expansive soils can run into billions of pounds as cost of maintenance or redesign of the road structure. The study has proven that cement and lime are mostly used in subgrade stabilisation. However, processed waste materials are effective for use as cement and lime replacement in road subgrade stabilisation using chemical stabilisation techniques. Waste materials and industrial by-products possess characteristics and engineering properties that can be found in cement and lime making these wastes materials a suitable substitute for cement and lime in road subgrade stabilisation.

It has been established in this study that the use of waste materials in subgrade stabilisation is cheaper compared to using cement and lime. Although the process of transforming waste materials used as additives in subgrade stabilisation is associated with some amount of greenhouse gas emission, this study has shown that the amount of greenhouse gas emitted during the processing of waste materials is far less compared to the carbon dioxide emitted during cement production. This makes the use of waste in subgrade stabilisation more sustainable, environmentally friendly and cost-effective. The availability of possessed waste materials to meet the current demand of subgrade stabilisation has been investigated and proven in this study, that there is enough processed waste available to meet the current demand. The future of sustainable engineering and achieving the United Nation Sustainable Development Goals (Goal 9: Industry, Innovation, and Infrastructure; Goal 12: Responsible Consumption and Production, and Goal 13: Climate Action) can be feasible when a conscious effort is made to use waste materials in road subgrade stabilisation [121].

\section{Conclusion and Recommendations}

Efforts have been made by many countries and organisations to tackle the challenges of climate change which is caused by human activities. Activities within the engineering and construction sector have contributed largely to the high amount of carbon dioxide in the atmosphere, which is the main cause of climate change. The use of traditional additives such as cement and lime in road subgrade stabilisation has contributed negatively to the environment due to the emission of greenhouse gas, pollution of water bodies, ecosystems and the destruction of natural resources during cement production. The greener ways of road subgrade stabilisation established in this study using non-traditional additives (such as waste materials and industrial by-products) in subgrade stabilisation have always been successful.

The study has proven that processed waste materials in subgrade stabilisation is sustainable, less costly, environmentally friendly and effective in enhancing the engineering properties of expansive subgrade materials. the availability of processed waste and industrial by-products to meet current demand has been established in this study. This study reveals the possibility of using waste materials like cement and lime replacement in road construction due to their cementitious properties, engineering properties and characteristics of these waste which as similar to cement and lime.

Based on the findings of this review, the following recommendations are proposed:

1. Research should be conducted to investigate new /novel and more sustainable waste materials that can be used in road subgrade stabilisation.

2. Companies and firms should encourage contractors by giving them some incentives for using sustainable waste materials in road construction. This will help achieve the global fight against climate change by 2050.

3. Strict rules or legislation should be put in place during the bidding process for contracts to ensure a certain amount of sustainable waste materials are used in construction. 
4. Further investigation should be conducted into the whole life cycle cost of road stabilised with waste materials compared to cement and lime stabilised subgrade. This will provide a wider picture of the cost benefits of using waste materials in road construction

5. Further investigation can be carried out in the future to determine long-term durability and how elevated and freezing temperatures can affect subgrade materials stabilised using processed waste.

Author Contributions: Conceptualisation, S.J.A. and S.Y.A.; methodology, S.Y.A. and S.J.A.; validation, S.Y.A. and S.J.A.; formal analysis, S.Y.A. and S.J.A.; investigation, S.Y.A. and S.J.A.; resources, S.J.A., C.A.B. and A.-M.M.; data curation, S.Y.A. and S.J.A.; writing-original draft preparation, S.Y.A. and S.J.A.; writing - review and editing, S.Y.A., S.J.A. and C.A.B.; visualisation, S.J.A., C.A.B. and A.-M.M.; supervision, S.J.A., C.A.B. and A.-M.M.; project administration, C.A.B., A.-M.M. and S.J.A. All authors have read and agreed to the published version of the manuscript.

Funding: This research did not receive any specific grant from funding agencies in the public, commercial, or not-for-profit sector.

Institutional Review Board Statement: Not Applicable.

Informed Consent Statement: Not Applicable.

Acknowledgments: The authors acknowledge the advice, comments and suggestions from anonymous reviewers significantly improved the quality of this paper.

Conflicts of Interest: The authors declare that they have no conflict of interest associated with this publication and no financial support has been given to influence the outcome of this work.

\section{References}

1. López-Lara, T.; Hernández-Zaragoza, J.; Horta-Rangel, J.; Rojas-González, E.; López-Ayala, S.; Castaño, V. Expansion reduction of clayey soils through Surcharge application and Lime Treatment. Case Stud. Constr. Mater. 2017, 7, 102-109. [CrossRef]

2. Amakye, S.Y.; Abbey, S.J. Understanding the performance of expansive subgrade materials treated with non-traditional stabilisers: A review. Clean. Eng. Technol. 2021, 4, 100159. [CrossRef]

3. Jones, L.D.; Jefferson, I. Institution of civil engineers manuals series. In Expansive Soils; ICE Publishing British Geological Survey: Nottingham, UK, 2012; pp. 413-441. [CrossRef]

4. Eyo, E.; Ng'Ambi, S.; Abbey, S.J. Incorporation of a nanotechnology-based additive in cementitious products for clay stabilisation. J. Rock Mech. Geotech. Eng. 2020, 12, 1056-1069. [CrossRef]

5. Abbey, S.J.; Ngambi, S.; Ganjian, E. Development of Strength Models for Prediction of Unconfined Compressive Strength of Cement/Byproduct Material Improved Soils. Geotech. Test. J. 2017, 40, 20160138. [CrossRef]

6. Federica, C.; Idiano, D.; Massimo, G. Sustainable management of waste-to-energy facilities. Renew. Sustain. Energy Rev. 2014, 33, 719-728.

7. Wang, J.X. Expansive Soil and Practice in Foundation Engineering. PhD. Thesis, P.E. Programs of Civil Engineering Programs Louisiana Tech University, Ruston, LA, USA, 2016. Available online: https://www.ltrc.lsu.edu/ltc_16/pdf/presentations/10 -University\%20Transportation\%20Centers\%20[Part\%201]-Characterization\%20of\%20Expansive\%20Soils\%20in \%20Northern\% 20Louisiana.pdf (accessed on 7 March 2021).

8. Jones, L.D.; Jefferson, I. Institution of Civil Engineers Manuals Series 2019. Available online: http://nora.nerc.ac.uk/id/eprint/ 17002/1/C5_expansive_soils_Oct.pdf (accessed on 18 January 2021).

9. Jalal, F.E.; Xu, Y.; Jamhiri, B.; Memon, S.A. On the Recent Trends in Expansive Soil Stabilization Using Calcium-Based Stabilizer Materials (CSMs): A Comprehensive Review. Adv. Mater. Sci. Eng. 2020, 2020, 1-23. [CrossRef]

10. Sabat, A. A Study on Some Geotechnical Properties of Lime Stabilised Expansive Soil -Quarry Dust Mixes. Int. J. Emerg. Trends Eng. Dev. 2012, 1, 42-49.

11. Elarabi, H. Damage Mechanism of Expansive Soils Damage Mechanism of Expansive Soils 2010. Available online: Gov.uk/pdf/ GEHO1111BVDF-E-E.pdf (accessed on 13 April 2020).

12. Osinubi, K.; Ijimdiya, T.S.; Nmadu, I. Lime Stabilization of Black Cotton Soil Using Bagasse Ash as Admixture. Adv. Mater. Res. 2009, 62-64, 3-10. [CrossRef]

13. Nelson, J.D.; Miller, D.J. Expansive Soils: Problems and Practice in Foundation and Pavement Engineering, 1st ed.; Wiley: New York, NY, USA, 1992; ISBN 0471511862.

14. Hossain, A.S.M.F.; Sultana, N.; Bhowmic, S.; Hoque, M.S.; Shantana, F.A. Modification of expansive soil using recycled plastic bottle chips. J. Geotech. Stud. 2019. [CrossRef] 
15. British Geological Survey. Available online: https://www.bgs.ac.uk/geology-projects/shallow-geohazards/clay-shrink-swell/ (accessed on 17 August 2021).

16. White, J.D.; Vennapusa, P. Low-cost rural surface alternatives: Literature review and recommendations 2013. InTrans Project Reports. 28. Available online: https:/ /lib.dr.iastate.edu/intrans_reports/28 (accessed on 16 March 2021).

17. The geological society. 2012. Available online: https://www.geolsoc.org.uk/Geoscientist/Archive/March-2014/Cracking-up-inLincolnshire (accessed on 16 March 2021).

18. Eyo, E.U.; Ng'Ambi, S.; Abbey, S.J. Performance of clay stabilized by cementitious materials and inclusion of zeolite/alkaline metals-based additive. Transp. Geotech. 2020, 23, 100330. [CrossRef]

19. Al-Rawas, A.A.; Goosen, F.A. Expansive Soils: Recent Advances in Characterization and Treatment; Taylor \& Francis: London, UK, 2006. [CrossRef]

20. Reda, A.; Ibrahim, E.; Houssami, L. A Cure for Swelling 2016. Available online: https://dar.com/news/details/a-cure-forswelling (accessed on 21 February 2021).

21. Eyo, E.U.; Abbey, S.J.; Ngambi, S.; Ganjian, E.; Coakley, E. Incorporation of a nanotechnology-based product in cementitious binders for sustainable mitigation of sulphate-induced heaving of stabilised soils. Eng. Sci. Technol. Int. J. 2020, 24, 436-448. [CrossRef]

22. Zaid, A. Swelling Expansion and Dilation of Soil 2017. Available online: https://www.slideshare.net/AhmedZaid11/swellingexpansion-and-dilation-of-soil (accessed on 11 February 2021).

23. Huggett, J. Clay Minerals; Elsevier: Amsterdam, The Netherlands, 2015. [CrossRef]

24. Eyo, E.; Ng'Ambi, S.; Abbey, S. Investigative Study of Behaviour of Treated Expansive Soil Using Empirical Correlations. IFCEE 2018 2018, 373-384. [CrossRef]

25. Uddin, F. Montmorillonite: An Introduction to Properties and Utilization; IntechOpen: London, UK, 2018. [CrossRef]

26. Dakshanamurthy, V.; Raman, V. A Simple Method of Identifying an Expansive Soil. Soils Found. 1973, 13, 97-104. [CrossRef]

27. ACPA Concrete Pavement Technology Series. Available online: http://1204075.sites.myregisteredsite.com/downloads/TS/EB2 04P/TS204.2P.pdf (accessed on 13 January 2021).

28. Murray, H.H. Chapter 2 structure and Composition of the Clay Minerals and their Physical and Chemical Properties. Dev. Clay Sci. 2006, 2, 7-31. [CrossRef]

29. Bananezhad, B.; Islami, M.R.; Ghonchepour, E.; Mostafavi, H.; Tikdari, A.M.; Rafiei, H.R. Bentonite clay as an efficient substrate for the synthesis of the super stable and recoverable magnetic nanocomposite of palladium $\left(\mathrm{Fe}_{3} \mathrm{O}_{4} /\right.$ Bentonite-Pd). Polyhedron 2019, 162, 192-200. [CrossRef]

30. Jaradat, K.A.; Darbari, Z.; Elbakhshwan, M.; Abdelaziz, S.L.; Gill, S.K.; Dooryhee, E.; Ecker, L.E. Heating-freezing effects on the orientation of kaolin clay particles. Appl. Clay Sci. 2017, 150, 163-174. [CrossRef]

31. Oti, J.E. The Development of Unfired Clay Building Materials for Sustainable Building Construction 2010. Available online: https://unilearn.southwales.ac.uk/webapps/blackboard/content/listContent.jsp? course_id=_141532_1\&content_id=_2 997727_1\&mode=reset (accessed on 15 February 2021).

32. British Plastic Federation (2019). Polypropylene. Available online: http://www.bpf.co.uk/plastipedia/polymers/pp.aspx (accessed on 16 March 2021).

33. Behak, L. Soil Stabilization with Rice Husk Ash. Rice Technol. Prod. 2017, 29. [CrossRef]

34. Khatib, J.M.; Baalbaki, O.; ElKordi, A.A. Waste and supplementary cementitious materials in concrete. Woodhead Publ. Ser. Civ. Struct. Eng. 2018, 493-511. [CrossRef]

35. Ghassemi, M.; Andersen, P.K.; Ghassemi, A.; Chianelli, R.R. Hazardous Waste from Fossil Fuels. Encycl. Energy 2004, 119-131. [CrossRef]

36. Gholhaki, M.; Kheyroddin, A.; Hajforoush, M.; Kazemi, M. An investigation on the fresh and hardened properties of selfcompacting concrete incorporating magnetic water with various pozzolanic materials. Constr. Build. Mater. 2018, 158, 173-180. [CrossRef]

37. Lafarge Cement UK. Manufacturing Process of Silica Fume 2012. Available online: https:/ /www.aggregate.com/ (accessed on 17 February 2021).

38. Miorslags. Available online: http:/ / miorslags.com/ggbs.html (accessed on 14 February 2021).

39. Bianco Construction \& Industrial Supplies. Available online: https:/ /www.bianco.com.au/product/view/7008 (accessed on 16 March 2021).

40. Guichon Valves. Manufacturing Process of Polypropylene 2019. Available online: https://guichon-valves.com/pp-valves/ (accessed on 17 August 2021).

41. Tomar, A.; Sharma, T.; Singh, S. Strength properties and durability of clay soil treated with mixture of nano silica and Polypropylene fiber. Mater. Today: Proc. 2020, 26, 3449-3457. [CrossRef]

42. Mindiamart, 2021. Available online: https://www.indiamart.com/proddetail/alkali-resistant-glass-fiber-21702650255.html (accessed on 16 March 2021).

43. Amakye, S.Y.; Abbey, S.J.; Olubanwo, A.O. Consistency and mechanical properties of sustainable concrete blended with brick dust waste cementitious materials. SN Appl. Sci. 2021, 3, 1-12. [CrossRef]

44. Thakur, I.C.; Kisku, N.; Singh, J.P.; Kumar, S. Properties of concrete incorporated with GGBS. Int. J. Res. Eng. Technol. 2016, 5, 275-281. Available online: https:/ /ijret.org/volumes/2016v05/i08/IJRET20160508046.pdf (accessed on 7 March 2021). 
45. Kalantari, B.; Prasad, A.; Huat, B.B.K. Cement and Silica Fume Treated Columns to Improve Peat Ground. Arab. J. Sci. Eng. 2012, 38, 805-816. [CrossRef]

46. Khalil, A.A.; Siswomiharjo, W.; Sunarintyas, S. Effect of non dental glass fiber orientation on transverse strength of dental fiber reinforced composite. J. Teknosains 2017, 5, 104-110. [CrossRef]

47. Prasad, P.D.; Nagarnaik, P.B.; Gajbhiye, A.R. Utilization of solid waste for soil stabilization: A Review. Electron. J. Geotech. Eng. 2012. Available online: https://www.researchgate.net/publication/267723862_Utilization_of_Solid_Waste_for_Soil_ Stabilization_A_Review (accessed on 21 February 2021).

48. Ahmad, S. Study of Concrete Involving Use of Waste Paper Sludge Ash as Partial Replacement of Cement. IOSR J. Eng. 2013, 3, 6-15. [CrossRef]

49. Zorluer, I.; Afyon Kocatepe University; Gucek, S. The usability of industrial wastes on soil stabilization. Rev. De La Construcción 2020, 19, 80-89. [CrossRef]

50. Yilmaz, F.; Kamiloğlu, H.; Şadoğlu, E. Soil Stabilization with Using Waste Materials against Freezing Thawing Effect. Acta Phys. Pol. A 2015, 128, 80-89. [CrossRef]

51. RILON. Polypropylene Fibre: Main Characteristics, Application, products and Structure 2020. Available online: https:// rilonfibers.com/blog/polypropylene-fiber/ (accessed on 28 February 2021).

52. Arena, U.; Zaccariello, L.; Mastellone, M.L. Tar removal during the fluidized bed gasification of plastic waste. Waste Manag. 2009, 29, 783-791. [CrossRef] [PubMed]

53. US Department of Transportation. Available online: https://www.fhwa.dot.gov/pavement/recycling/fach01.cfm (accessed on 7 March 2021).

54. Chakraborty, S.; Mahmud, T.; Islam, M.M.; Islam, M.S. Use of paper industry waste in making low cost concrete 2014. 2nd International Conference on Advances in Civil Engineering. [ICACE-2014] CUET, Chittagong, Bangladesh. Available online: https: / / www.researchgate.net/publication/293810073_Use_of_Paper_Industry_Waste_in_Making_Low_Cost_Concrete (accessed on 19 March 2021).

55. James, J.; Pandian, P.K. Industrial Wastes as Auxiliary Additives to Cement/Lime Stabilization of Soils. Adv. Civ. Eng. 2016, 2016, 1-17. [CrossRef]

56. Central Electricity Authority. Report on fly ash generation at coal/lignite based thermal power station and its utilisation in the country for the year 2014-15, New Delhi, India. Available online: https: / cea.nic.in/wp-content/uploads/2020/04/flyash_final_ 1415.pdf (accessed on 17 August 2021).

57. The World Bank. 2021. Available online: https://datatopics.worldbank.org/what-a-waste/trends_in_solid_waste_management. html (accessed on 16 March 2021).

58. Hoornweg, D.; Bhada-Tata, P. What a Waste: A Global Review of Solid Waste Management; World Bank: Washington, DC, USA, 2012.

59. Heidrich, C.; Feuerborn, H.; Weir, A. Coal combustion production: A Global Perspective. In Proceedings of the World of Coal Ash Conference, Lexington, KY, USA, 22-25 April 2013.

60. Motz, H.; Ehrenberg, A.; Mudersbach, D. Dry solidification with heat recovery of ferrous slag. In Proceedings of the Third International Slag Valorisation Symposium, Leuven, Belgium, 19-20 March 2013; pp. 37-55.

61. Mišík, M.; Burke, I.T.; Reismüller, M.; Pichler, C.; Rainer, B.; Mišíková, K.; Mayes, W.M.; Knasmueller, S. Red mud a byproduct of aluminum production contains soluble vanadium that causes genotoxic and cytotoxic effects in higher plants. Sci. Total Environ. 2014, 493, 883-890. [CrossRef]

62. Tayibi, H.; Choura, M.; López, F.A.; Alguacil, F.J.; López-Delgado, A. Environmental impact and management of phosphogypsum. J. Environ. Manag. 2009, 90, 2377-2386. [CrossRef]

63. Kumal, P.; Rajour, A.; Siddiqui, R. Biological remediation of alkaline cement kiln dust for sustainable development. In Industrial, Medical and Environmental Application of Microorganisms; Wageningen Academic Publishers: Madrid, Spain, 2014; pp. 52-58.

64. Central Electricity Authority. Report on fly ash generation at coal/lignite based thermal power station and its utilisation in the country for the year 2011-12 and 2012-14, New Delhi, India. Available online: https://cea.nic.in/wp-content/uploads/2020/04/ fly_ash_final_111213.pdf (accessed on 17 August 2021).

65. Teja, S.L.; Kumar, S.S.; Needhidasan, S. Stabilisation of expansive soil using brick dust. Int. J. Pure Appl. Math. 2018, 119, 903-910. Available online: https:/ / acadpubl.eu/hub/2018-119-17/4/375.pdf (accessed on 7 March 2021).

66. Bhavsar, S.; Patel, A. Analysis of Swellings and Shrinkage Properties of Expansive Soil Using Brick Dust as a Stabilizer. 2014. Available online: https://www.researchgate.net/publication/269762906_Analysis_of_Swelling_Shrinkage_Properties_ of_Expansive_Soil_using_Brick_Dust_as_a_Stabilizer (accessed on 13 February 2021).

67. Kumar, J.K.; Kumar, V.P. Experimental Analysis of Soil Stabilisation Using e-Waste; Saveetha School of Engineering, SIMATS: Chennai, India, 2019; Volume 22, pp. 456-459.

68. Khan, T.A.; Taha, M.R.; Khan, M.M.; Shah, S.A.R.; Aslam, M.A.; Waqar, A.; Khan, A.R.; Waseem, M. Strength and Volume Change Characteristics of Clayey Soils: Performance Evaluation of Enzymes. Minerals 2020, 10, 52. [CrossRef]

69. Kumar, A.; Kumar, A.; Ved, P. Stabilization of Expansive Soil with Lime and Brick Dust. Int. J. All Res. Educ. Sci. Methods 2016, 4(9), 2455-6211. Available online: http://www.ijaresm.com/uploaded_files/document_file/Ajay_kumarNcca.pdf (accessed on 13 March 2021).

70. Pokale, K.R.; Borkar, Y.R.; Jichkar, R.R. Experimental Investigation for Stabilization of Black Cotton Soil By using waste materialDust. Int. Res. J. Eng. Technol. 2015, 2, 726. 
71. Neha, P.; Trived, M.K. Improvement of Pavement Soil Subgrade by Using Burnt Brick Dust. Int. J. Res. Appl. Sci. Eng. Technol. 2017, 5, 218-221.

72. Soil Stabilization using Brick Kiln Dust and waste Coir Fibre. Int. J. Recent Technol. Eng. 2019, 8, 2574-2578. [CrossRef]

73. Kinjal, C.C.; Padvi, H.S.; Patel, H.V.; Patel, J.A.; Tandel, J. Literature Review of Soil Stabilisation Using Different Materials. Int. J. Tech. Innov. Mod. Eng. Sci. 2018. Available online: http://ijtimes.com/papers/finished_papers/IJTIMESV04I02150228175419.pdf (accessed on 21 February 2021).

74. Hairulla; Betaubun, P. The effect of using brick waste on the stabilisation of soft soil due to the unconfined compression. J. Basic Appl. Sci. Res. 2016, 6, 1-8. Available online: https://www.textroad.com/pdf/JBASR/J.\%20Basic.\%20Appl.\%20Sci.\%20Res.,\%20 6[2]1-8,\%202016.pdf (accessed on 12 February 2021).

75. Rank, K.; Bhanderi, J.; Mehta, J.V. Using Brick Dust Manufacturing Waste and Cement Dust Manufacturing Waste as Stabilising Materials for Expansive Soil 2020. Available online: http:/ / www.jetir.org/papers/JETIR2002078.pdf (accessed on 14 February 2021).

76. Estabragh, A.R.; Jahani, A.; Javadi, A.A.; Babalar, M. Assessment of different agents for stabilisation of a clay soil. Int. J. Pavement Eng. 2020, 1-11. [CrossRef]

77. Sharma, A.K.; Sivapullaiah, P. Ground granulated blast furnace slag amended fly ash as an expansive soil stabilizer. Soils Found. 2016, 56, 205-212. [CrossRef]

78. Prasad, S.D.; Prasad, D.S.V.; Raju, G.V.R. Stabilisation of black cotton soil using ground granulated blast furnace slag and plastic fibres. Int. J. Recent Technol. Eng. 2019. Available online: https://www.ijrte.org/wp-content/uploads/papers/v7i6c2/F1115047 6C219.pdf (accessed on 21 February 2021).

79. Duyu, H.; Tania, T.; Dhake, M. Study on the effect of ground granulated blast furnace slag on the properties of black cotton soil and red soil. Int. J. Sci. Res. 2015. Available online: https://www.ijsr.net/archive/v6i5/ART20173214.pdf (accessed on 18 January 2021).

80. Yadu, L.; Tripathi, R.K. Effects of Granulated Blast Furnace Slag in the Engineering Behaviour of Stabilised Soft Soil 2013. Available online: https://www.sciencedirect.com/science/article/pii/S1877705813000209 (accessed on 11 February 2021).

81. Ashraf, A.; Sunil, A.; Dhanya, J.; Joseph, M.; Varghese, M.; Veena, M. Soil stabilisation using plastic bottles. In Proceedings of the Indian Geotechnical Conference, Kochi, Kerala, India, 15-17 December 2011. Available online: https: / / www.researchgate.net/ publication/279999540_SOIL_STABILIISATION_USING_RAW_PLASTIC_BOTTLES (accessed on 12 February 2021).

82. Wani, I.A.; Sheikh, I.M.; Maqbool, T.; Kumar, V. Experimental investigation on using plastic wastes to enhance several engineering properties of soil through stabilization. Mater. Today Proc. 2021, 45, 4571-4574. [CrossRef]

83. Tang, C.-S.; Shi, B.; Gao, W.; Chen, F.; Cai, Y. Strength and mechanical behavior of short polypropylene fiber reinforced and cement stabilized clayey soil. Geotext. Geomembranes 2007, 25, 194-202. [CrossRef]

84. Ali, N.; Raj, V.S. Effect of polypropylene fibre on swelling behaviour of black cotton soil. Mater. Today Proc. 2020. [CrossRef]

85. Murthi, P.; Saravanan, R.; Poongodi, K. Studies on the impact of polypropylene and silica fume blended combination on the material behaviour of black cotton soil. Mater. Today Proc. 2020, 39, 621-626. [CrossRef]

86. Vakili, A.H.; Ghasemi, J.; bin Selamat, M.R.; Salimi, M.; Farhadi, M.S. Internal erosional behaviour of dispersive clay stabilized with lignosulfonate and reinforced with polypropylene fiber. Constr. Build. Mater. 2018, 193, 405-415. [CrossRef]

87. Ding, M.; Zhang, F.; Ling, X.; Lin, B. Effects of freeze-thaw cycles on mechanical properties of polypropylene fibre and cement stabilised clay. Cold Reg. Sci. Technol. 2018. [CrossRef]

88. Booth, C.A.; Hammond, F.N.; Lamond, J.E.; Proverbs, D.G. Solutions to Climate Change Challenges in the Built Environment; Wiley-Blackwells: Oxford, UK, 2012.

89. Ping, L.; Zhao, G.; Lin, X.; Gu, Y.; Liu, W.; Cao, H.; Huang, J.; Xu, J. Feasibility and Carbon Footprint Analysis of Lime-Dried Sludge for Cement Production. Sustainability 2020, 12, 2500. [CrossRef]

90. Benhelal, E.; Zahedi, G.; Shamsaei, E.; Bahadori, A. Global strategies and potentials to curb $\mathrm{CO}_{2}$ emissions in cement industry. J. Clean. Prod. 2013, 51, 142-161. [CrossRef]

91. Geng, Y.; Wang, Z.; Shen, L.; Zhao, J. Calculating of $\mathrm{CO}_{2}$ emission factors for Chinese cement production based on inorganic carbon and organic carbon. J. Clean. Prod. 2019, 217, 503-509. [CrossRef]

92. Onn, C.C.; Mo, K.H.; Radwan, M.K.H.; Liew, W.H.; Ng, C.G.; Yusoff, S. Strength, Carbon Footprint and Cost Considerations of Mortar Blends with High Volume Ground Granulated Blast Furnace Slag. Sustainability 2019, 11, 7194. [CrossRef]

93. International Energy Agency (IEA). $\mathrm{CO}_{2}$ Emission for Combustion Highlights 2010. Available online: https://www.iea.org/co2 highlights (accessed on 24 March 2021).

94. Anand, K.B.G.; Agrawel, S.; Dobriyal, A. Stabilisation of Cohesive Soil Using Demolished Brick Waste 2014, Innovations and Advances in Civil Engineering towards Green and Sustainable Systems. Available online: https://www.researchgate.net/ publication/326972521_Stabilization_of_Cohesive_Soil_using_Demolished_Brick_Waste (accessed on 12 February 2021).

95. Al-Baidhani, A.A.; Al-Taie, A. Review of brick waste in expansive soil stabilisation and other civil engineering applications. J. Geotech. Stud. 2019, 4, 14-23.

96. Sachin, N.B.; Hiral, B.J.; Priyanka, K.S.; Ankit, P. Effect of burnt brick dust on engineering properties on expansive soil. Int. J. Res. Eng. Technol. 2014, 3, 433-441.

97. Reddy, S.S.; Prasad, A.C.S.V.; Krishna, N.V. Lime-stabilised black cotton soil and brick powder mixture as subbase material. Adv. Civ. Eng. 2018, 18, 1-10. 
98. Wild, S.; Kinuthia, J.M.; Jones, G.I.; Higgins, D.D. Effect of partial substitution of lime with ground granulated blast furnace slag (GGBS) on the strength properties of lime-stabilised sulphate-bearing clay soils. Eng. Geol. 1998, 51, 37-53. [CrossRef]

99. Corrêa-Silva, M.; Miranda, T.; Rouainia, M.; Araújo, N.; Glendinning, S.; Cristelo, N. Geomechanical behaviour of a soft soil stabilised with alkali-activated blast-furnace slags. J. Clean. Prod. 2020, 267, 122017. [CrossRef]

100. Obuzor, G.; Kinuthia, J.; Robinson, R. Soil stabilisation with lime-activated-GGBS-A mitigation to flooding effects on road structural layers/embankments constructed on floodplains. Eng. Geol. 2012, 151, 112-119. [CrossRef]

101. Celik, E.; Nalbantoglu, Z. Effects of ground granulated blastfurnace slag (GGBS) on the swelling properties of lime-stabilized sulfate-bearing soils. Eng. Geol. 2013, 163, 20-25. [CrossRef]

102. Gokul, V.; Steffi, D.A.; Kaviya, R.; Harni, C.; Dharani, S. Alkali activation of clayey soil using GGBS and NaOH. Mater. Today: Proc. 2020, 43, 1707-1713. [CrossRef]

103. Kassa, R.B.; Workie, T.; Abdela, A.; Fekade, M.; Saleh, M.; Dejene, Y. Soil Stabilization Using Waste Plastic Materials. Open J. Civ. Eng. 2020, 10, 55-68. [CrossRef]

104. Consoli, N.C.; Da Silva Lopes, L.; Foppa, D.; Heineck, K.S. Key parameters dictating strength of lime/cement-treated soils. Proc. Inst. Civ. Eng. Geotech. Eng. 2009, 162, 111-118. [CrossRef]

105. Boardman, D.I.; Glendinning, S.; Rogers, C.D.F. Development of stabilisation and solidification in lime-clay mixes. Geotechnique 2001, 51, 533-543. [CrossRef]

106. Neville, A.M. Properties of Concrete, 5th ed.; Wiley: New York, NY, USA; Harlow, England, 2011. Available online: https: //pdfcoffee.com/properties-of-concrete-fifth-edition-a-m-neville-pdf-pdf-free.html (accessed on 13 September 2021).

107. Prusinski, J.R.; Bhattacharja, S. Effectiveness of Portland cement and lime in stabilising clay soils. Transp. Res. Rec. 1999, 1652, 215-227. [CrossRef]

108. Walker, P. Review and Experimental Comparison of erosion tests or Earth Blocks. In Terra 2000 Postprints: 8th International Conference on the Study and Conservation of Earthen Architecture, Torquay, Devon, UK, May 2000; James \& James: London, UK, 2000.

109. Gooding, D.E.; Thomas, T.H. The potential of cement stabilised building blocks as an urban building material in developing countries. DTU working paper No.44. 1995. Available online: https://warwick.ac.uk/fac/sci/eng/research/grouplist/ structural/dtu/pubs/wp/wp44/wp44_.pdf (accessed on 17 August 2021).

110. Lea, F.M. The Chemistry of Cement and Concrete, 3rd ed.; Edward Arnold: London, UK, 1980.

111. Gross, J.; Adaska, W. Guide to Cement-Stabilised Subgrade Soils. 2020. Available online: https://intrans.iastate.edu/app/ uploads/2020/05/guide_to_CSS.pdf (accessed on 23 September 2021).

112. Taylor, H.F.W. Cement Chemistry, 2nd ed.; Thomas Telford Publishing: London, UK, 1997; pp. $19-43$.

113. Oner, A.; Akyuz, S. An experimental study on optimum usage of GGBS for the compressive strength of concrete. Cem. Concr. Compos. 2007, 29, 505-514. [CrossRef]

114. Kartini, K.; Rohaidah, M.N.; Zuraini, Z.A. Performance of ground clay bricks as partial cement replacement in grade 30 concrete. Int. Sch. Sci. Res. Innov. 2012, 6, 312-315.

115. Seco, A.; Ramirez, F.; Miqueleiz, L.; Urmeneta, P.; García, B.; Prieto, E.; Oroz, E.P.A.V. Types of Waste for the Production of Pozzolanic Materials-A Review; BoD - Books on Demand: Norderstedt, Germany, 2012. [CrossRef]

116. Davidovits, J. Geopolymers and gropolymeric materials. J. Therm. Anal. 1989, 35, 429-441. [CrossRef]

117. Srinivasan, K.; Sivakumar, A. Geopolymer Binders: A Need for Future Concrete Construction. ISRN Polym. Sci. 2013, 2013, 1-8. [CrossRef]

118. Gourley, J.T. Geopolymers, opportunities for environmentally friendly construction material. In Proceedings of the International Conference and Exhibition on Adaptive materials for a Modern society (Materials '30), Sydney. Australia, 30-31 August 2003.

119. Palomo, A.; Grutzeck, M.W.; Blanco, M.T. Alkali-activated fly ashes: A cement for the future. Cem. Concr. Res. 1999, $29,1323-1329$. [CrossRef]

120. Van Jaarsveld, J.G.S.; Van Deventer, J.S.J.; Lukey, G.C. The characteristics of source materials in fly ash-based geopolymers. Mater. Lett. 2003, 57, 1272-1280. [CrossRef]

121. United Nation Sustainable Development Goals. Available online: https://sdgs.un.org/goals/goal9 (accessed on 17 August 2021 ). 